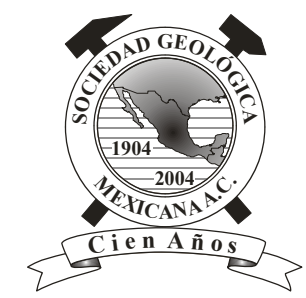

\title{
Cenozoic volcanism and extension in northwestern Mesa Central, Durango, México
}

\author{
Isidro Loza-Aguirre ${ }^{1,2, *}$, Ángel F. Nieto-Samaniego ${ }^{1}$, Susana A. Alaniz-Álvarez ${ }^{1}$ \\ Carlos Ortega-Obregón ${ }^{1}$ \\ ${ }^{1}$ Centro de Geociencias, Universidad Nacional Autónoma de México, Campus Juriquilla, Boulevard Juriquilla No. 3001, Juriquilla, \\ Querétaro, México, CP 76230. \\ ${ }^{2}$ Centro de Geociencias, Posgrado en Ciencias de la Tierra, Universidad Nacional Autónoma de México, Campus Juriquilla, \\ Boulevard Juriquilla No. 3001, Juriquilla, Querétaro, México, CP 76230. \\ *isla@geociencias.unam.mx
}

\begin{abstract}
The Santiago Papasquiaro region is located in the northwest portion of the Mesa Central and is characterized by Tertiary Sierra Madre Occidental lithology. Geologic mapping and dating of key units using U-Pb laser ablation method on zircons has identified three different lithostratigraphic groups. These include: (1) early Eocene felsic volcanic rocks, consisting of the Antigua ignimbrite [51.75 $+0.35 /-0.45 \mathrm{Ma}]$; (2) late Eocene - early Oligocene felsic to intermediate volcanic rocks, consisting of the Altamira ignimbrite [38.8 \pm 1.0 Ma], El Cazadero andesite [ages of 37.2 +0.30/-0.40 Ma and 35.95+0.45/-0.5 Ma], a dioritic intrusion, the Venadita rhyolite, Puente Negro ignimbrite [34.0+0.50/-0.70 Ma], Los Fresnos ignimbrite and Balín ignimbrite [33.2 +0.50/-0.20 Ma]; and (3) late Oligocene to Quaternary sedimentary and volcanic mafic rocks comprising the Santiago sedimentary formation, basalts equivalent to Metates Formation and Neogene to Quaternary continental non-consolidated deposits. Within the studied area, the main volcanic pulse of the Sierra Madre Occidental volcanic province corresponds to the second group, which lasted $c a .5 \mathrm{Ma}$. Older rocks are represented by a single outcrop of the Antigua ignimbrite, and the younger units are mainly continental clastic sediments intercalated with sporadic mafic alkaline volcanic rocks that record a major change in the tectonic regime. Extension that began in late Eocene - Oligocene gradually tilted the late Eocene - early Oligocene volcanic sequence and formed the NNW-trending Santiago Papasquiaro half-graben, which is the northernmost and earliest structure of the Río Chico-Otinapa graben. NW-striking faults of the San Luis-Tepehuanes fault system were synchronous with the development of the Santiago Papasquiaro half-graben. The deformation propagated gradually to the south, forming the NNW Río Chico-Otinapa graben by the early-middle Miocene, and to the east-southeast in the Santiaguillo graben. A recent minor extensional deformation accommodated by NE-striking faults was probably related to seismic deformation of the Nuevo Ideal zone, approximately $40 \mathrm{~km}$ southeast of the study area.
\end{abstract}

Keywords: Cenozoic, stratigraphy, extension, Mesa Central, Sierra Madre Occidental, graben system.

\section{Resumen}

La región de Santiago Papasquiaro está localizada en el noroeste de la Mesa Central y está caracterizada por litología terciaria de la Sierra Madre Occidental. Mediante la cartografía geológica del área y la realización de fechamientos isotópicos por el método U-Pb de ablación láser en circones se reconocieron tres grupos litoestratigráficos. Estos incluyen: (1) rocas volcánicas félsicas del Eoceno temprano, que consiste de la ignimbrita Antigua [51.75 +0.35/-0.45 Ma]; (2) rocas volcánicas félsicas a intermedias del Eoceno tardio-Oligoceno temprano, que incluye a la ignimbrita Altamira [38.7 $\pm 1.0 \mathrm{Ma}$ ], la andesita El Cazadero [edades de 37.2 $+0.30 /-0.40$ Ma y 35.95 +0.45/-0.5 Ma], una intrusión diorítica, la riolita Venadita, la ignimbrita Puente Negro [34.0 +0.50/-0.70 Ma], la ignimbrita Los Fresnos y la ignimbrita Balin [33.2+0.50/-0.20 Ma]; y (3) rocas sedimentarias continentales y volcánicas 
máficas del Oligoceno tardio-Cuaternario que comprenden a la formación Santiago, basaltos equivalentes a la Formación Metates y sedimentos continentales no consolidados del Neógeno-Cuaternario. En la zona de estudio el pulso volcánico más importante de la provincia volcánica de la Sierra Madre Occidental corresponde al segundo grupo, que duró ca. 5 Ma. Las rocas más antiguas están representadas por un afloramiento de la ignimbrita Antigua, y las unidades más jóvenes son principalmente sedimentos clásticos continentales intercalados con esporádicas rocas volcánicas máficas alcalinas, que registran un cambio importante en el régimen tectónico. La extensión que comenzó en el Eoceno tardio-Oligoceno basculó gradualmente a la secuencia volcánica del Eoceno tardí-Oligoceno temprano y formó al semigraben de Santiago Papasquiaro de rumbo NNW, que es la estructura más septentrional, y primera en desarrollarse del graben de Rio Chico-Otinapa. La actividad en las fallas de rumbo NW del Sistema de fallas San LuisTepehuanes fue sincrónica con el desarrollo del semigraben de Santiago Papasquiaro. La deformación se propagó gradualmente hacia el Sur, desarrollándose el graben de Río Chico-Otinapa de rumbo NNW durante el Mioceno temprano-medio, y hacia el Este-Sureste en el graben de Santiaguillo. La deformación menor extensional reciente acomodada por fallas de rumbo NE, estuvo relacionada probablemente con la actividad sísmica en la zona de Nuevo Ideal, $40 \mathrm{~km}$ al sureste del área de estudio.

Palabras clave: Cenozoico, Estratigrafia, Extensión, Mesa Central, Sierra Madre Occidental, sistema de graben.

\section{Introduction}

Santiago Papasquiaro is located in central Mexico in the northwestern portion of the Mesa Central physiographic province (MC) (Nieto-Samaniego et al., 2005), almost $130 \mathrm{~km}$ northwest from Durango City (Figure $1 \mathrm{~A}, \mathrm{~B})$. The most recent geological studies in the zone are the Santiago Papasquiaro geological maps published by the Servicio Geológico Mexicano at scales of 1:250000 (Mungía-Rojas et al., 2000) and 1:50000 (Luévano-Pinedo et al., 2003), as well as the study of Nieto-Samaniego et al. (2012) about the stratigraphy, deformation and seismicity in the Santiaguillo graben, located $40 \mathrm{~km}$ southeast of Santiago Papasquiaro (Figure $1 \mathrm{C}$ ). This region is characterized by outcrops of Tertiary volcanic rocks of the Sierra Madre Occidental volcanic province (SMOc) (Ferrari et al., 2005) (Figure $1 \mathrm{C}$ and 2).

Regional structures in the study area strike from NE to NW (Mungía-Rojas et al., 2000; Luévano-Pinedo et al., 2003; Nieto-Samaniego et al., 2005). NE faults are poorly known, although in some regions of the SMOc they act as transfer zones between domains of different tilts (Henry and Aranda-Gómez, 2000). NNE to NNW-striking grabens are located within the Sierra Madre Occidental (SMOc) and the Mesa Central (MC), one of the most noticeable of these structures is the $\sim 150 \mathrm{~km}$ long Río Chico-Otinapa graben (RCOG) (Figures 1 and 3) (Aranda-Gómez et al., 1997; Henry and Aranda-Gómez, 2000). In previous studies the NW faults have been considered part of the San LuisTepehuanes Fault System (SLTFS) (Nieto-Samaniego et al., 2005, 2012). The SLTFS is a major structure that crosses central Mexico from San Luis de La Paz, Gto., to Tepehuanes, Dgo., consisting of normal faults that had been active from Eocene to Quaternary time (Figure $1 \mathrm{C}$ ). In the NW segment, southeast of Santiago Papasquiaro, the SLTFS had associated Quaternary magmatism and seismic activity (Figures $1 \mathrm{C}$ and 2) (Nieto-Samaniego et al., 2005, 2012). Part of the northwestern segment of the SLTFS intersects the northernmost portion of the RCOG within the study area (Figures 1 and 3).

Representative volcanic units of the study area were dated with $\mathrm{U}-\mathrm{Pb}$ on zircons using a spot of 23 microns of laser ablation attached to an inductively coupled plasma mass spectrometer (LA-ICP-MS). All of these ages were obtained at the Laboratorio de Estudio Isotópicos (LEI), Centro de Geociencias, UNAM. Detailed methodology of this technique and data reduction procedures used in this laboratory are described by Solari et al. (2010) and Solari and Tanner (2011). Due to the lack of common lead $\left({ }^{204} \mathrm{~Pb}\right)$ values (e.g., from feldspars) of these rocks, we use the algebraic method of correction of Andersen (2002) with a careful analysis on Tera-Wasserburg concordia diagrams. Analyses that show evidence of inclusions or lead loss were discarded during data reduction procedure and only the most concordant ages were used to determine the mean age using the Zircon Age Extractor script from Ludwig (2008).

The knowledge of the Tertiary lithostratigraphy and volcanic activity pulses, as well as the relative ages of major structures and their relationship with volcanism, in the Santiago Papasquiaro region is certainly poor compared with other areas of the MC as Guanajuato, San Luis Potosí and Zacatecas (Nieto-Samaniego et al., 2005). The geologic mapping carried out on the 1:50000 scale G13C48 Santiago Papasquiaro topographic base map (INEGI, 2000), allows inferring the relationships among deformation, volcanic activity and major structures during Cenozoic time in this area, which are the main objectives of this work. Based on the geologic mapping and the new isotopic ages reported in this contribution, an improved lithostratrigraphic column and a reconstruction of the main volcanic and faulting events are proposed.

\section{Geological setting}

In this portion of the MC the lithological record 


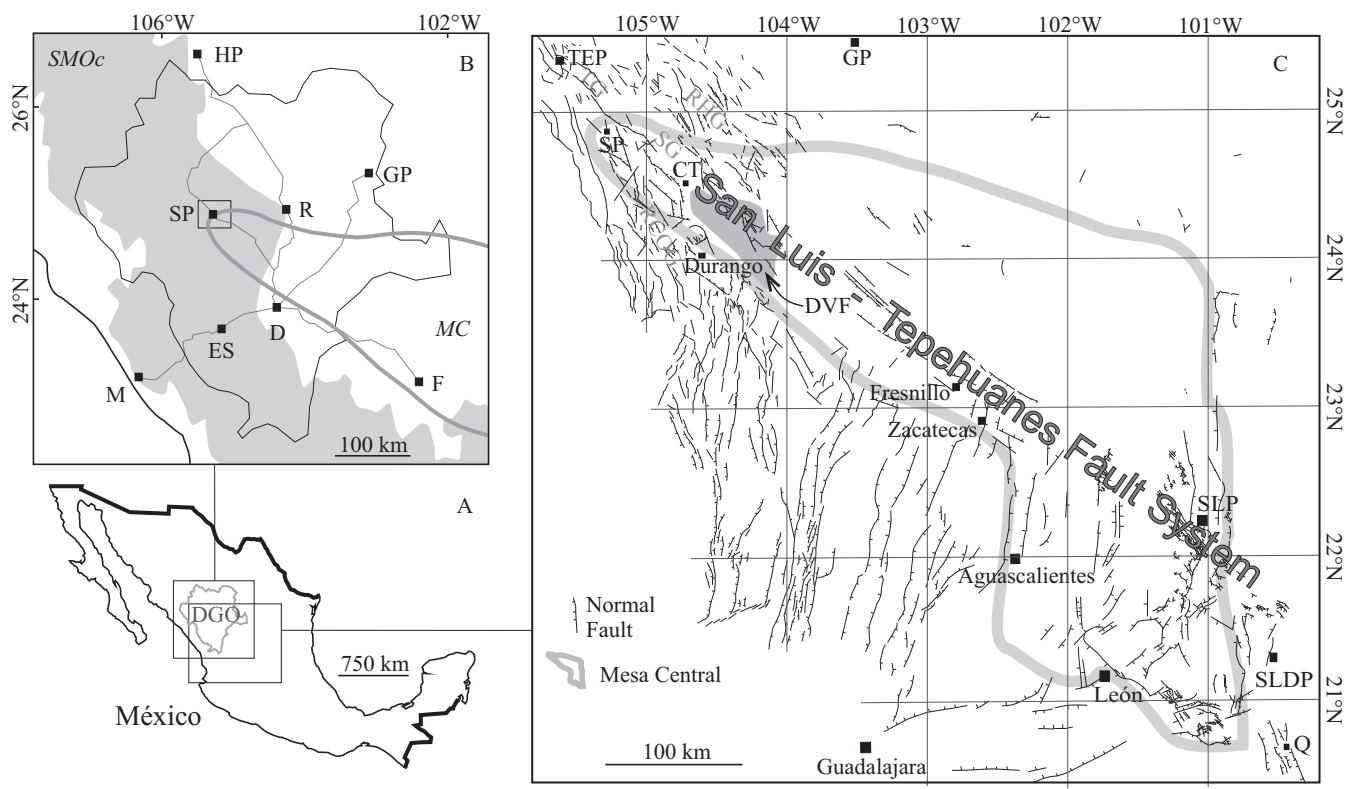

Figure 1. Geographic location of the study area. A) Durango State is located in central northwest México. B) Light gray thin lines represent the roads that connect the principal cities and towns in the region: Hidalgo del Parral (HP), Gómez Palacio (GP), Rodeo (R), Santiago Papasquiaro (SP), Mazatlán (M), El Salto (ES); Fresnillo (F), Durango (D). Gray shaded area represents the Sierra Madre Occidental volcanic province (SMOc) (Ferrari et al., 2005), and the Mesa Central (MC) is delimited by thick gray line (Nieto-Samaniego et al., 2005). The box enclosing SP represents the study area. C) Regional structural map of the Mesa Central and surroundings (Modified from Nieto-Samaniego et al., 2005). The San Luis - Tepehuanes Fault System has a NW general strike and a length of almost $600 \mathrm{~km}$ from San Luis de La Paz in the southeast (SLDP) to Tepehuanes in the northwest (TEP). In the northwest in gray text: Tepehuanes Graben (TG), Rodeo Half Graben (RHG), Santiaguillo Graben (SG) and Río Chico-Otinapa Graben (RCOG). Durango Quaternary Volcanic Field (DVF) is northeast of Durango City. San Luis Potosí City (SLP), Querétaro City (Q). The Mesa Central is delimited by thick gray line.

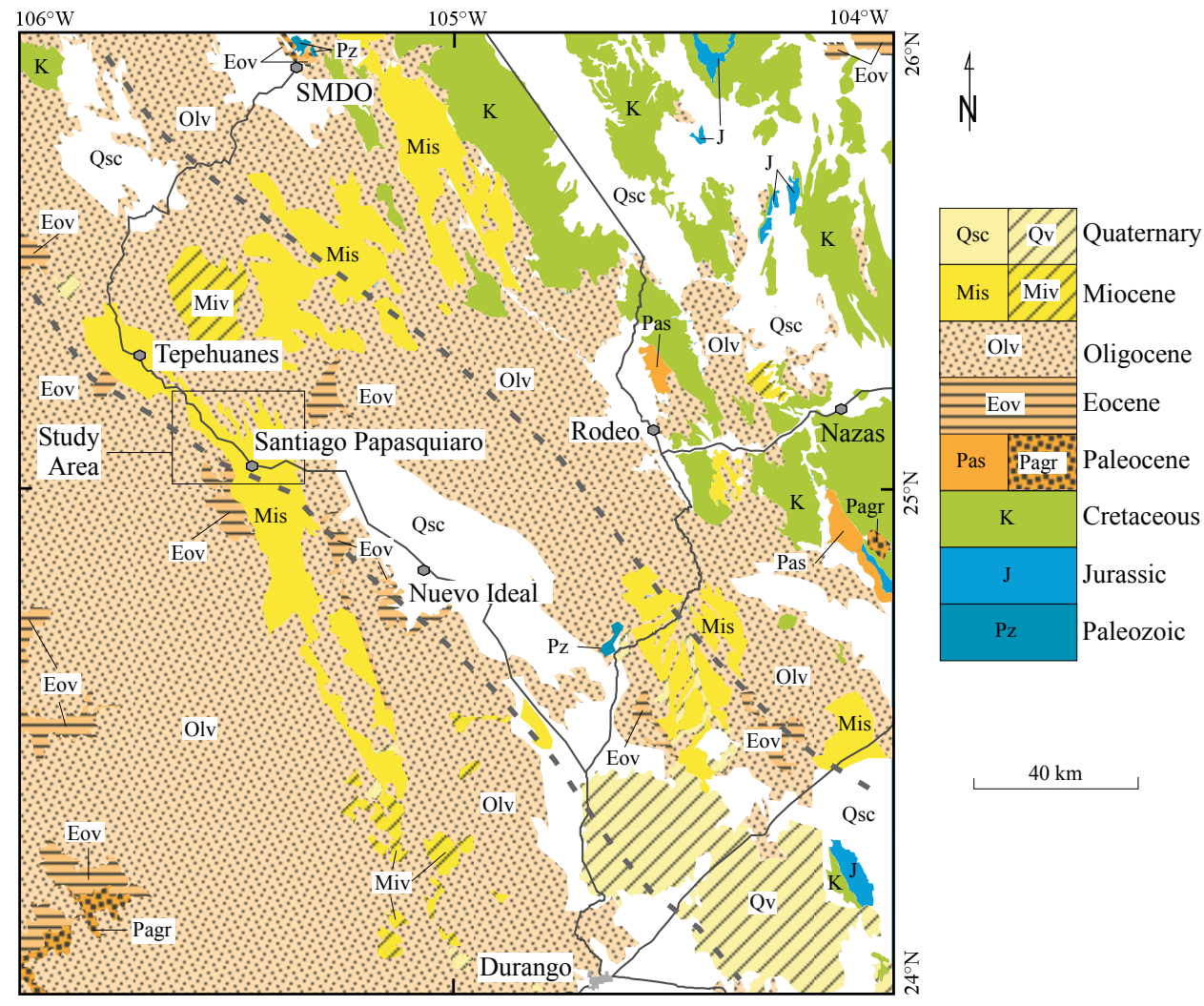

Figure 2. Regional geologic map of the northwestern Mesa Central in the region between Durango and Santa Maria del Oro (SMDO). Includes Santiago Papasquiaro and Durango 1:250000 scale maps. Geology modified from: Mungía-Rojas et al. (1998), Mungía-Rojas et al. (2000), Ferrari et al. (2005), Nieto-Samaniego et al. (2005), SGM (2007). Segmented gray lines delimitate the influence zone of the San Luis-Tepehuanes fault system in this region. 


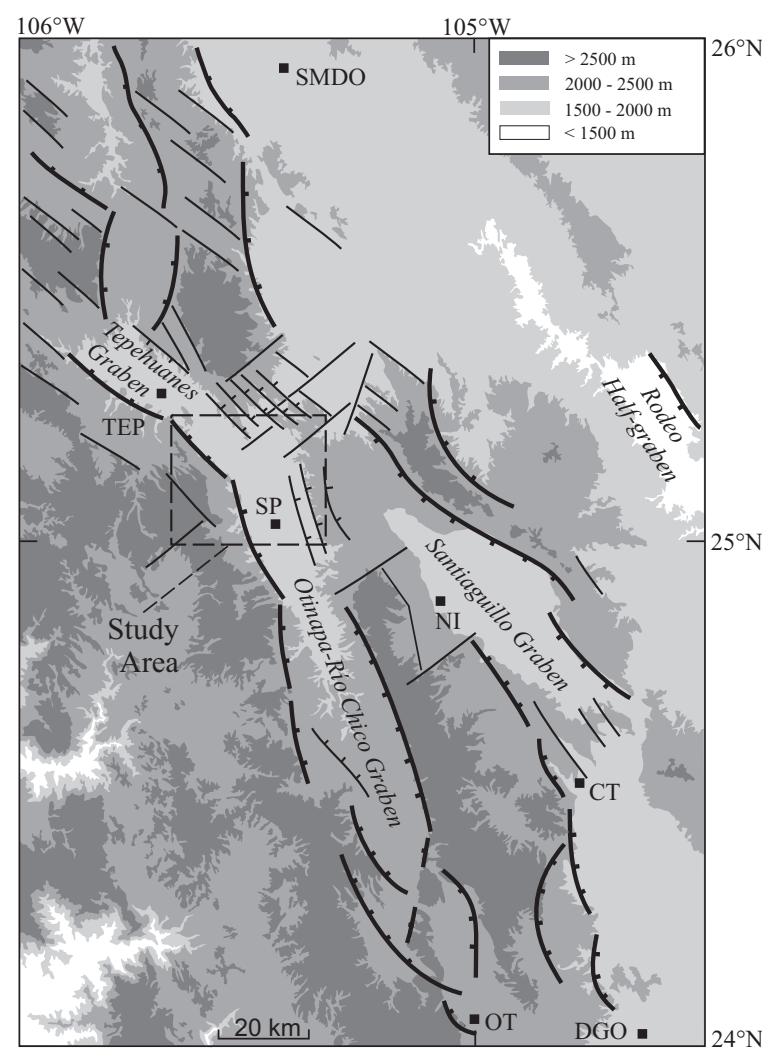

Figure 3. Elevation map of the region between Durango (DGO) and Santa Maria del Oro (SMDO). The principal faults that control the depressions in the region are shown; thinner lines represent the secondary structures. The most notorious depressions are the Tepehuanes graben, the Rodeo half graben, the Santiaguillo graben and the Río Chico-Otinapa graben. The rectangle in segmented line delimitates the study area of the present work. Other important cities in the region: Santiago Papasquiaro (SP), Tepehuanes (TEP), Nuevo Ideal (NI), Canatlán (CT) and Otinapa (OT).

includes Paleozoic to Quaternary rocks (Figure 2). Gneiss and schist, with a metamorphic age of $\sim 252 \mathrm{Ma}$ ( $\mathrm{Ar}-\mathrm{Ar}$ on moscovite, Iriondo et al., 2003), crop out $\sim 100 \mathrm{~km}$ to the east-southeast of Santiago Papasquiaro, and schist with a metamorphic age of $326 \pm 26 \mathrm{Ma}$ (K-Ar, AraujoMendieta and Arenas-Partida, 1986) crops out $\sim 100 \mathrm{~km}$ to the north. Unconformably overlying the Paleozoic units are clastic and carbonate Jurassic and Cretaceous marine rocks (Zaldívar and Garduño, 1984; Aranda-García et al., 1987; Contreras-Montero et al., 1988; Córdoba, 1988) that were folded and thrusted during the Laramide Orogeny (Nieto-Samaniego et al., 2005). These Mesozoic rocks are covered by continental conglomerates, Eocene to Miocene mainly acid to intermediate volcanic rocks of the SMOc, and Oligocene-Miocene to Pleistocene basic volcanic rocks (McDowell and Keizer, 1977; Swanson et al., 1978; McDowell and Clabaugh, 1981; Córdoba, 1988; AguirreDíaz and McDowell, 1991; Mungía-Rojas et al., 2000; Luhr et al., 2001; Ferrari et al., 2005; Nieto-Samaniego et al., 2005; Solé et al., 2007; Nieto-Samaniego et al., 2012). Miocene to Quaternary alluvial and lacustrine deposits fill continental basins, and Quaternary alkaline basalts top the lithologic column (Figure 2) (Nieto-Samaniego et al., 2005).

The Mesa Central has undergone extension since the late Eocene (Nieto-Samaniego et al., 2005). Previous studies have defined two main events in this region: the first one occurred in early-late Oligocene and the second one in late Miocene. These events are characterized by the development of high angle normal faults that formed graben-type tectonic depressions (Figures 1 and 3) (Aguirre-Díaz and McDowell, 1993; Aranda-Gómez et al., 1997; Henry and ArandaGómez, 2000; Luhr et al., 2001; Ferrari et al., 2005; NietoSamaniego et al., 2005, 2012). Although the timing of the regional extension is generally known, information about the age, geometry and kinematics of individual grabens and half grabens in the region is scarce, with the exception of the Santiaguillo graben (Nieto-Samaniego et al., 2012), the Rodeo half-graben (Luhr et al., 2001) and the southernmost part of the Río Chico-Otinapa graben (Aranda-Gómez et al., 1997; Henry and Aranda-Gómez, 2000).

\section{Local stratigraphy}

\subsection{Early Eocene volcanism}

\subsubsection{Antigua ignimbrite}

The pyroclastic deposits located at the bottom of the stratigraphic sequence are named in the present work as Antigua ignimbrite. This unit crops out in the northern part of the Santiago Papasquiaro-Los Altares highway and its base is not exposed (Figure 4, Tables 1 and 2). The Antigua ignimbrite unconformably underlies the El Cazadero andesite. A U-Pb age of $51.75+0.35 /-0.45 \mathrm{Ma}$ (Figure 5, Tables 3 and 4) was obtained by LA-ICP-MS on zircons of a representative sample of this unit (Fres-b). We interpret this age as the crystallization time of magmatic zircons that should be very close to the time of rock emplacement (cooling), because the date was obtained from the younger coherent group of concordant ages obtained from the border of zircons. The Antigua ignimbrite has similar lithological characteristics and equivalent stratigraphic position as rocks reported by Aguirre-Díaz and McDowell (1991) in the Nazas region, east of the study area (Figure 2). The volcanic sequence near Nazas consists of silicic pyroclastic rocks, intermediate lava flows and domes, with ages between 48.8 \pm 3 and $40.3 \pm 1 \mathrm{Ma}(\mathrm{K}-\mathrm{Ar}$, on plagioclase, biotite, sanidine and hornblende).

\subsection{Late Eocene-early Oligocene volcanism}

\subsubsection{Altamira ignimbrite}

The Altamira ignimbrite is a pyroclastic deposit that crops out in the eastern and southeastern parts of the study area (Figure 4, Tables 1 and 2). This unit is the A1 member of the Altamira ignimbrite reported by Nieto-Samaniego et al. (2012) in the Nuevo Ideal-Canatlán region, $40 \mathrm{~km}$ 

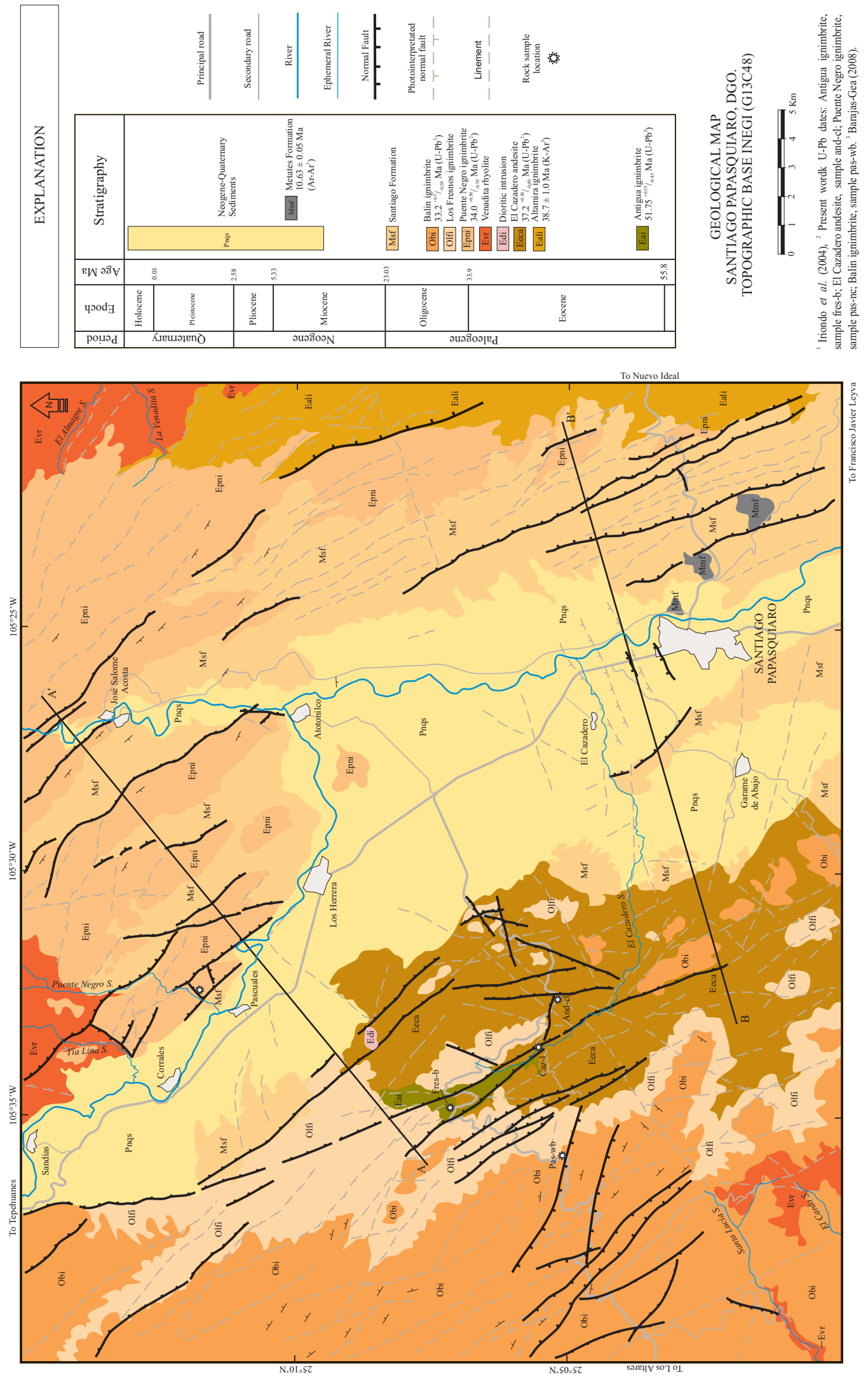

Figure 4. Geologic map of Santiago Papasquiaro, Durango State, scale 1:50,000 made on the topographic base map G13-C48 (INEGI, 2000). Shown are the isotopic ages obtained during the present work and those previously published by others. The Santiago Papasquiaro valley has a NW strike in the northern portion and a NNW strike in the center and south portions. 
Table 1. Outcrop characteristics of lithostratigraphic units

\begin{tabular}{|c|c|c|c|c|c|c|c|c|c|c|c|}
\hline \multirow{2}{*}{ Unit Name } & \multirow{2}{*}{ Color } & \multirow{2}{*}{ Welding } & \multicolumn{2}{|c|}{ Lithics } & \multicolumn{2}{|c|}{ Pumice } & \multicolumn{2}{|c|}{ Phenocrysts } & \multirow{2}{*}{ Matrix } & \multirow{2}{*}{$\begin{array}{c}\text { Estimated } \\
\text { Thickness } \\
\text { (m) }\end{array}$} & \multirow{2}{*}{$\begin{array}{l}\text { Age } \\
\text { (Ma) }\end{array}$} \\
\hline & & & Size $(\mathrm{cm})$ & Type/ Charc. & Size $(\mathrm{cm})$ & Charc. & Size $(\mathrm{mm})$ & Mineral & & & \\
\hline Metates Formation & dark gray & - & - & - & - & - & 5 & & & $\begin{array}{c}10 \\
(\max .)\end{array}$ & $\begin{array}{c}10.63 \\
10.95 \\
(\mathrm{Ar}-\mathrm{Ar})\end{array}$ \\
\hline $\begin{array}{l}\text { Santiago } \\
\text { formation }\end{array}$ & $\begin{array}{l}\text { light brown- } \\
\text { yellow }\end{array}$ & - & $1 / 4-1(\mathrm{~mm})-60 \mathrm{~cm}$ & subA-subR & $1 / 4-1(\mathrm{~mm})-5 \mathrm{~cm}$ & subA-subR & 01-may & $\begin{array}{c}\text { qz, } \\
\text { Kfs } \\
\text { > bio }\end{array}$ & fine sand & $\begin{array}{c}100 \\
\text { (mean) }\end{array}$ & - \\
\hline Balín ignimbrite & $\begin{array}{l}\text { light gray- } \\
\text { purple }\end{array}$ & mod- high & 10 & subA & 10 & $\operatorname{modF}$ & 5 & $\mathrm{qz}, \mathrm{Kfs}$, bio & ashy & 200 & $\begin{array}{c}33.2 \\
(\mathrm{U}-\mathrm{Pb})\end{array}$ \\
\hline $\begin{array}{c}\text { Los Fresnos } \\
\text { ignimbrite }\end{array}$ & $\begin{array}{l}\text { red } \\
\text { pink }\end{array}$ & $\begin{array}{c}\text { mod } \\
\text { mod- high }\end{array}$ & $\begin{array}{c}1>3 \\
15\end{array}$ & $\begin{array}{l}\text { aph } \\
\text { an, rhy }\end{array}$ & $\begin{array}{c}1 \\
10\end{array}$ & $\begin{array}{l}\operatorname{notF} \\
\operatorname{modF}\end{array}$ & $\begin{array}{l}3 \\
5\end{array}$ & $\begin{array}{c}\mathrm{qz} \\
\mathrm{qz}, \text { bio }\end{array}$ & $\begin{array}{l}\text { ashy } \\
\text { ashy }\end{array}$ & 150 & - \\
\hline $\begin{array}{l}\text { Puente Negro } \\
\text { ignimbrite }\end{array}$ & light gray & $\bmod$ & 3 & subA & 5 & $\operatorname{modF}$ & 5 & $\mathrm{qz}, \mathrm{Kfs}$, bio & ashy & 100 & $\begin{array}{c}34 \\
(\mathrm{U}-\mathrm{Pb})\end{array}$ \\
\hline Venadita rhyolite & red & - & - & - & - & - & & $\mathrm{qz}, \mathrm{Kfs}$ & devitrified glass & $\begin{array}{c}100 \\
(\max .)\end{array}$ & - \\
\hline Dioritic intrusion & & - & - & - & - & - & 05-ago & $\mathrm{pl}, \mathrm{am}$ & & & - \\
\hline $\begin{array}{l}\text { El Cazadero } \\
\text { andesite }\end{array}$ & $\begin{array}{c}\text { green } \\
\text { purple } \\
\text { red }\end{array}$ & - & - & - & - & - & 5 & $\mathrm{am}, \mathrm{pl}$ & glassy & $\begin{array}{c}200 \\
\text { (max.) }\end{array}$ & $\begin{array}{c}35.95 \\
37.2 \\
(\mathrm{U}-\mathrm{Pb})\end{array}$ \\
\hline $\begin{array}{c}\text { Altamira } \\
\text { ignimbrite }\end{array}$ & pink & high & 5 & $\begin{array}{c}\text { A, mafic, aph, }>> \\
\text { Met, Sed }\end{array}$ & 8 & highF & & $\mathrm{qz}, \mathrm{Kfs}$, bio, hbl & glassy & $\begin{array}{c}80 \\
\text { (min.) }\end{array}$ & $\begin{array}{c}38.8 \\
(\mathrm{~K}-\mathrm{Ar})\end{array}$ \\
\hline $\begin{array}{c}\text { Antigua } \\
\text { ignimbrite }\end{array}$ & pink & high & 15 & $\begin{array}{l}\text { A, dark red, } \\
\text { compact, aph }\end{array}$ & 10 & $\operatorname{modF}$ & 5 & $\mathrm{qz}, \mathrm{Kfs}$, bio & ashy & $\begin{array}{c}50 \\
\text { (min.) }\end{array}$ & $\begin{array}{c}51.75 \\
(\mathrm{U}-\mathrm{Pb})\end{array}$ \\
\hline
\end{tabular}

Charc.: Characteristics.

subA: Subangular. subR: Subrounded. aph: Aphanitic. A: Angular.

qz: Quartz. Kfs: Potassium Feldspar. bio: Biotite. pl: Plagioclase. am: Amphibole. hbl: Hornblende.

mod: Moderate. modF: Moderately Flattened. notF: Not Flattened. highF: Highly Flattened.

an: Andesite fragments. rhy: Rhyolite fragments. Met: Metamorphic rock fragments. Sed: Sedimentary rock fragments.

southeast of the study area. Nieto-Samaniego et al. (2012) inferred that the olivine crystals (Table 2) observed in thin section must be fayalite because they appear as phenocrysts in association with quartz and K-feldspar. The Altamira ignimbrite unconformably underlies the Venadita rhyolite, Puente Negro ignimbrite and Santiago formation (Figure 4). In the Nuevo Ideal region, Nieto-Samaniego et al. (2012) obtained an age of $38.8 \pm 1.0 \mathrm{Ma}$ (K-Ar age, sanidine). This unit has lithological similarities and equivalent stratigraphic position as late Eocene-early Oligocene volcanic pulse rocks reported by Aguirre-Díaz and McDowell (1991) in the Nazas region, composed by rhyolitic domes and tuffs with ages from $34.0 \pm 0.8 \mathrm{Ma}$ to $29.5 \pm 1.0 \mathrm{Ma}$ (K-Ar ages, K-feldspar, plagioclase).

\subsubsection{El Cazadero andesite}

El Cazadero andesite consists of an intercalation of andesitic lava, breccia and tuff, as well as continental clastic deposits composed of andesite fragments, which crops out west of El Cazadero town, in the west-southwestern part of the study area (Figure 4). In previous studies this unit was named "andesite-andesitic breccia" (Mungía-Rojas et al., 2000; Luévano-Pinedo et al., 2003). General macroscopic and microscopic characteristics of lavas are shown in
Tables 1 and 2. In some outcrops along the Santiago Papasquiaro-Los Altares highway, the rock has isolated reabsorbed andesite fragments in red and pale brown flow bands. The andesitic breccia shows several tones of green with matrix-supported, subangular to subrounded volcanic rock fragments in a fine to medium grained matrix. A dark reddish brown deposit composed of coarse sandstone and shale unconformably underlies the volcanic breccia. The sandstone contains andesite fragments supported by silicic matrix. A light colored pyroclastic deposit that contains pumice and holes left by eroded pumice fragments is intercalated between clastic deposits and lavas of El Cazadero andesite. This deposit contains lithic fragments between $5 \mathrm{~mm}$ and $10 \mathrm{~cm}$ across, and isolated biotite crystals up to $5 \mathrm{~mm}$ in diameter. El Cazadero andesite overlies unconformably the Antigua ignimbrite. $\mathrm{U}-\mathrm{Pb}$ ages of two lavas of El Cazadero andesite were obtained by laser ablation inductively coupled plasma mass spectrometer (LA-ICP-MS) on zircons. Dating results were $37.2+0.30 /-$ $0.40 \mathrm{Ma}$ (Figure 6, Tables 3 and 5) for sample And-cl, and $35.95+0.45 /-0.5 \mathrm{Ma}$ (Figure 6, Tables 3 and 6) for sample $\mathrm{Caz}-1$. El Cazadero andesite has similar ages and lithology as Coneto andesite of the Nuevo Ideal region, which has reported ages of $35.0 \pm 0.6 \mathrm{Ma}$ (Ar-Ar on plagioclase, Nieto- 
Table 2. Petrographic summary of lithostratigraphic units.

\begin{tabular}{|c|c|c|c|c|}
\hline \multirow{2}{*}{ Unit Name } & \multirow{2}{*}{ Texture } & \multicolumn{3}{|c|}{ Phenocrysts } \\
\hline & & $\%$ & shape & mineral \\
\hline Metates Formation & $\begin{array}{l}\text { fine grain, holo - } \\
\text { hypocrystalline }\end{array}$ & $<10$ & subH- euH & $\mathrm{pl}$, bio, px \\
\hline $\begin{array}{l}\text { Santiago } \\
\text { formation }\end{array}$ & & oct- 40 & subA- subR & \\
\hline Balín ignimbrite & $\begin{array}{l}\text { medium grain, } \\
\text { hypocrystalline }\end{array}$ & 20 & subH- anH & $\mathrm{qz}, \mathrm{sa}, \mathrm{pl} \gg>$ bio \\
\hline $\begin{array}{l}\text { Los Fresnos } \\
\text { ignimbrite }\end{array}$ & $\begin{array}{l}\text { fine- medium } \\
\text { grain, } \\
\text { hypocrystalline }\end{array}$ & $20-30$ & subH- anH & qz, sa, bio, pl \\
\hline $\begin{array}{l}\text { Puente Negro } \\
\text { ignimbrite }\end{array}$ & $\begin{array}{l}\text { medium grain, } \\
\text { hypocrystalline }\end{array}$ & 10 & subH & qz, sa, pl, bio \\
\hline Venadita rhyolite & & oct-20 & subH & $\begin{array}{c}\mathrm{qz}, \mathrm{sa}, \mathrm{bio}, \mathrm{pl}, \mathrm{am}, \\
>>\mathrm{mag}\end{array}$ \\
\hline Dioritic intrusion & & $20-30$ & euH- subH & $\begin{array}{c}\mathrm{pl}, \mathrm{am}, \mathrm{qz} \\
\text { > ap, } \\
\mathrm{ms}\end{array}$ \\
\hline $\begin{array}{l}\text { El Cazadero } \\
\text { andesite }\end{array}$ & $\begin{array}{l}\text { medium grain } \\
\text { hypocrystalline }\end{array}$ & $<25$ & subH- euH & $\mathrm{am}, \mathrm{pl}, \mathrm{qz}$ \\
\hline $\begin{array}{l}\text { Altamira } \\
\text { ignimbrite }\end{array}$ & & & anH & $\begin{array}{c}\mathrm{qz}, \mathrm{sa}, \mathrm{bio}, \mathrm{hb}>> \\
\text { ox, ol }\end{array}$ \\
\hline Antigua ignimbrite & hypocrystalline & 20 & anH- subH & $\mathrm{qz}, \mathrm{sa}, \mathrm{bio}, \mathrm{hb}$ \\
\hline
\end{tabular}

subH: Subhedral. euH: Euhedral. anH: Anhedral. subA: Subangular. subR: Subrounded.

pl: Plagioclase. bio: Biotite. px: Pyroxene. qz: Quartz. sa: Sanidine. am: Amphibole. mag: Magnetite. ap: Apatite. ms: Muscovite. ox: Oxides. ol: Olivine.
Samaniego et al., 2012) and 40.15+0.35/0.95 Ma (U-Pb on zircons, Nieto-Samaniego et al., 2012).

\subsubsection{Venadita rhyolite}

In the present study the name of Venadita rhyolite was given to a group of lava domes that overlies the Altamira ignimbrite and the El Cazadero andesite (Figure 4). Outcrops of this unit can be observed in some streams like La Venadita and El Almagre in the northeast of the study area, Santa Lucia and El Cardo in the southwest, and Puente Negro and Tía Lina in the north (Figure 4). General macroscopic and microscopic characteristics are shown in Tables 1 and 2. Commonly, the rhyolite has basal vitrophyres and autobreccias as well as flow foliation. Spherulitic texture is developed in some outcrops. The matrix is devitrified and presents perlitic fractures in thin section. The Venadita rhyolite unconformably underlies the Puente Negro ignimbrite. Due to lithological features and stratigraphic position this unit has similarities with the rhyolitic dome of $34 \pm 0.8 \mathrm{Ma}$ reported in Nazas region (Aguirre-Díaz and McDowell, 1991). For that reason, we consider the Venadita rhyolite of late Eocene-early Oligocene age.

\subsubsection{Puente Negro ignimbrite}

Puente Negro ignimbrite is a massive pyroclastic deposit that crops out in the northern and northeastern parts of the study area (Figure 4, Tables 1 and 2). This unit forms large tilted plateaus in the central-northern a)

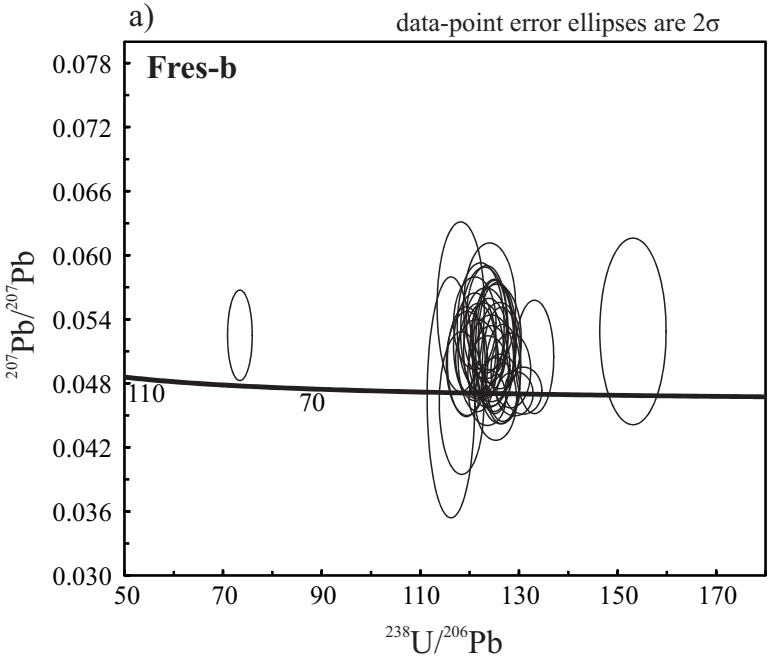

b)

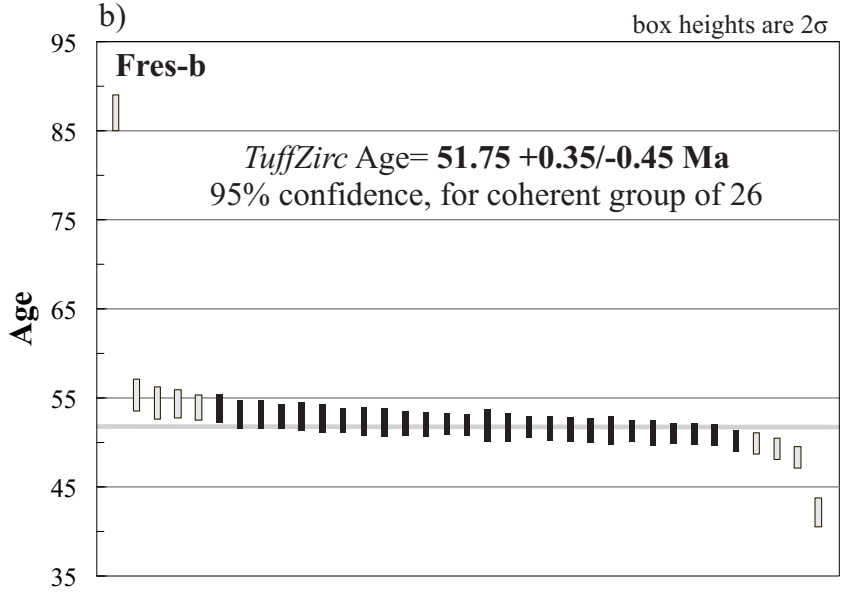

Figure 5. Zircon U-Pb data obtained by LA-ICP-MS from sample Fres- $b$ of the Antigua ignimbrite. a) Tera-Wasserburg diagram showing concordant data from sample Fres- $b$. Although many of the ellipses touch the concordant curve (which means that they could be considered concordant data), there are some ellipses that do not. Part of this problem is related to the lack of common lead values (as discussed in the introduction), as well as problems related to the fact that ablation (23 microns spot) took place probably in several layers (outer and inner layers) of the zircon that could be slightly different in age (therefore, different isotopic composition is mixed during analysis). b) Mean weight age diagram for this sample. 
Table 3. Results of the U-Pb isotopic dating.

\begin{tabular}{|c|c|c|c|c|c|c|}
\hline Unit Name & Sample & Location & Rock type & ${ }^{206} \mathrm{~Pb} /{ }^{238} \mathrm{U}$ mean age $(\mathrm{Ma})$ & $\begin{array}{c}\text { Confidence } \\
\%\end{array}$ & \# of Spots \\
\hline Balin Ignimbrite & Pas-wb & $105.59^{\circ} \mathrm{E}, 25.08^{\circ} \mathrm{N}$ & Ignimbrite & $33.2+0.50 /-0.20$ & 95 & 27 \\
\hline Puente Negro Ignimbrite & Pas-nc & $105.54^{\circ} \mathrm{E}, 25.19^{\circ} \mathrm{N}$ & Ignimbrite & $34.0+0.50 /-0.70$ & 94.3 & 14 \\
\hline El Cazadero Andesite & Caz-1 & $105.56^{\circ} \mathrm{E}, 25.09^{\circ} \mathrm{N}$ & Andesite & $35.95+0.45 /-0.5$ & 96.1 & 12 \\
\hline El Cazadero Andesite & And-cl & $105.54^{\circ} \mathrm{E}, 25.08^{\circ} \mathrm{N}$ & Andesite & $37.2+0.30 /-0.40$ & 95 & 33 \\
\hline Antigua Ignimbrite & Fres-b & $105.57^{\circ} \mathrm{E}, 25.11^{\circ} \mathrm{N}$ & Ignimbrite & $51.75+0.34 /-0.45$ & 95 & 26 \\
\hline -- & Gm-26 & $104.79^{\circ} \mathrm{E}, 24.93^{\circ} \mathrm{N}$ & Rhyolite & $56.4+0.50 /-0.70$ & 97.8 & 13 \\
\hline
\end{tabular}

part of the area (Figures 3 and 4). The Puente Negro ignimbrite overlies unconformably the Altamira ignimbrite and Venadita rhyolite, and underlies unconformably the Santiago formation and the Neogene-Quaternary continental sediments. A U-Pb age of $34.0+0.50 /-0.70 \mathrm{Ma}$ (Figure 7, Tables 3 and 7) was obtained from a representative sample $(P a s-n c)$. This unit is considered part of the late Eoceneearly Oligocene volcanic pulse.

\subsubsection{Los Fresnos ignimbrite}

Los Fresnos ignimbrite is a set of pyroclastic deposits that crop out west and northwest of Santiago Papasquiaro, and can be observed along the Santiago Papasquiaro-Los Altares highway (Figure 4, Tables 1 and 2). They have been grouped previously with other volcanic deposits and named as "rhyolitic tuff-ignimbrite" by Luévano-Pinedo et al. (2003). In the bottom of the Los Fresnos ignimbrite there are a series of pyroclastic-flow and fall deposits, with a total thickness of $2 \mathrm{~m}$. Individual layers are red and yellow and have thicknesses of less than $5 \mathrm{~cm}$. Los Fresnos ignimbrite overlies unconformably the Antigua ignimbrite, the El Cazadero andesite and the Venadita rhyolite, and underlies conformably the Balín ignimbrite. Los Fresnos ignimbrite has not been dated. However, its stratigraphic position indicates an early Oligocene age, including this unit as part of the late Eocene-early Oligocene ignimbritic pulse (Figure 4).

\subsubsection{Balín ignimbrite}

The name Balín ignimbrite was given to a unit composed of pyroclastic deposits that crop out in the western sector of the study area, along the Santiago Papasquiaro-Los Altares highway (Figure 4, Tables 1 and 2). In previous studies these rocks were grouped with other deposits and were named generically as "rhyolitic tuff-ignimbrite" (Luévano-Pinedo et al., 2003). In some outcrops, these deposits show pseudostratification and poorly developed columnar jointing. In the uppermost portion of the deposit are "pumice holes" up to $10 \mathrm{~cm}$ long, which are the voids left by eroded pumice fragments. Near the base of this unit, lithic fragments are bigger. The Balín ignimbrite overlies conformably Los Fresnos ignimbrite and discordantly the El Cazadero
Andesite. The U-Pb age obtained from the sample Pas- $w b$ is $33.2+0.50 /-0.20 \mathrm{Ma}$ (Figure 8, Tables 3 and 8). This dating places the Balín ignimbrite in the early Oligocene. Considering this age, the Balín ignimbrite is grouped within the late Eocene-early Oligocene ignimbritic pulse.

\subsubsection{Santiago formation}

The Santiago formation is the name proposed for epiclastic light brown-yellowish deposits of medium to coarse sand, gravel and conglomerate that crop out in the eastern, northern and western borders of the Santiago Papasquiaro valley (Figure 4, Tables 1 and 2). These deposits were named in previous works as "rhyolitic brecciarhyolitic tuff” (Luévano-Pinedo et al., 2003). The most accessible outcrops are along the Santiago PapasquiaroNuevo Ideal highway as well as along the Santiago Papasquiaro-Garame de Abajo road (Figure 4). The Santiago formation includes intercalations of continental deposits of sand and conglomerates that are moderately lithified. In the southernmost outcrops these strata are composed of fragments that range in size from medium to coarse sand. Interbedded with the fine grained deposits are some lenticular deposits where fragment size increases. In the northernmost deposits of this unit the fragments are almost $60 \mathrm{~cm}$. The source of these deposits probably was north of the study area because the clasts size increases toward the north. The Santiago formation overlies unconformably the Puente Negro ignimbrite and underlies unconformably basalt flows equivalent to the Metates Formation. This unit has similar lithological features and stratigraphic position as the Santa Inés Formation previously reported in Nazas by Aguirre-Díaz and McDowell (1991); these authors also described in the Nazas area 24 Ma mafic lavas overlying the Santa Inés Formation; mafic lavas of similar age had not been found in the Santiago Papasquiaro region. Taking into account its stratigraphic position, we propose a late Oligocene age for the Santiago Formation (Figure 4).

\subsection{Miocene}

\subsubsection{Basalt equivalent to the Metates Formation}

The Metates Formation was defined by Córdoba (1963) 


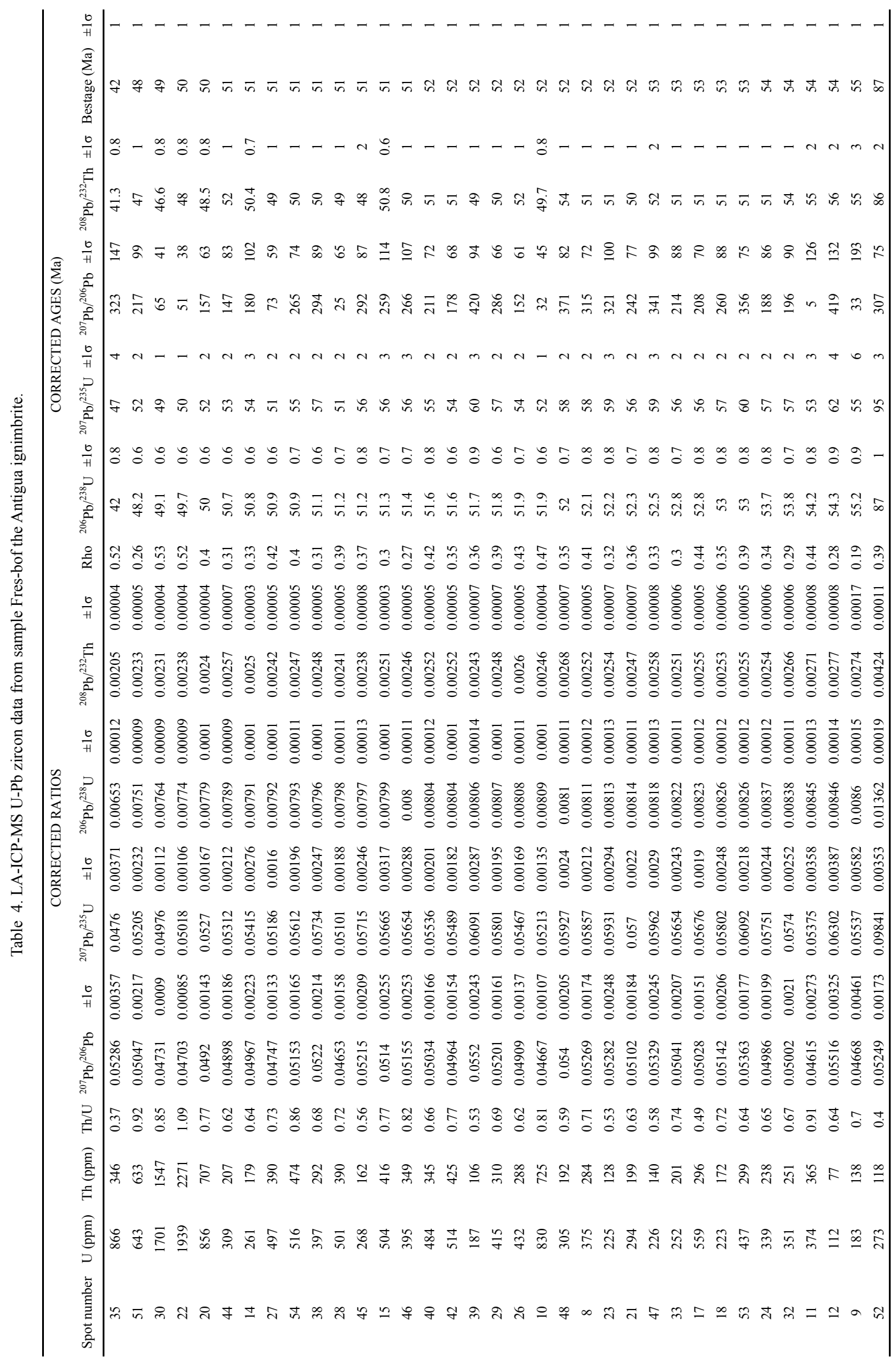



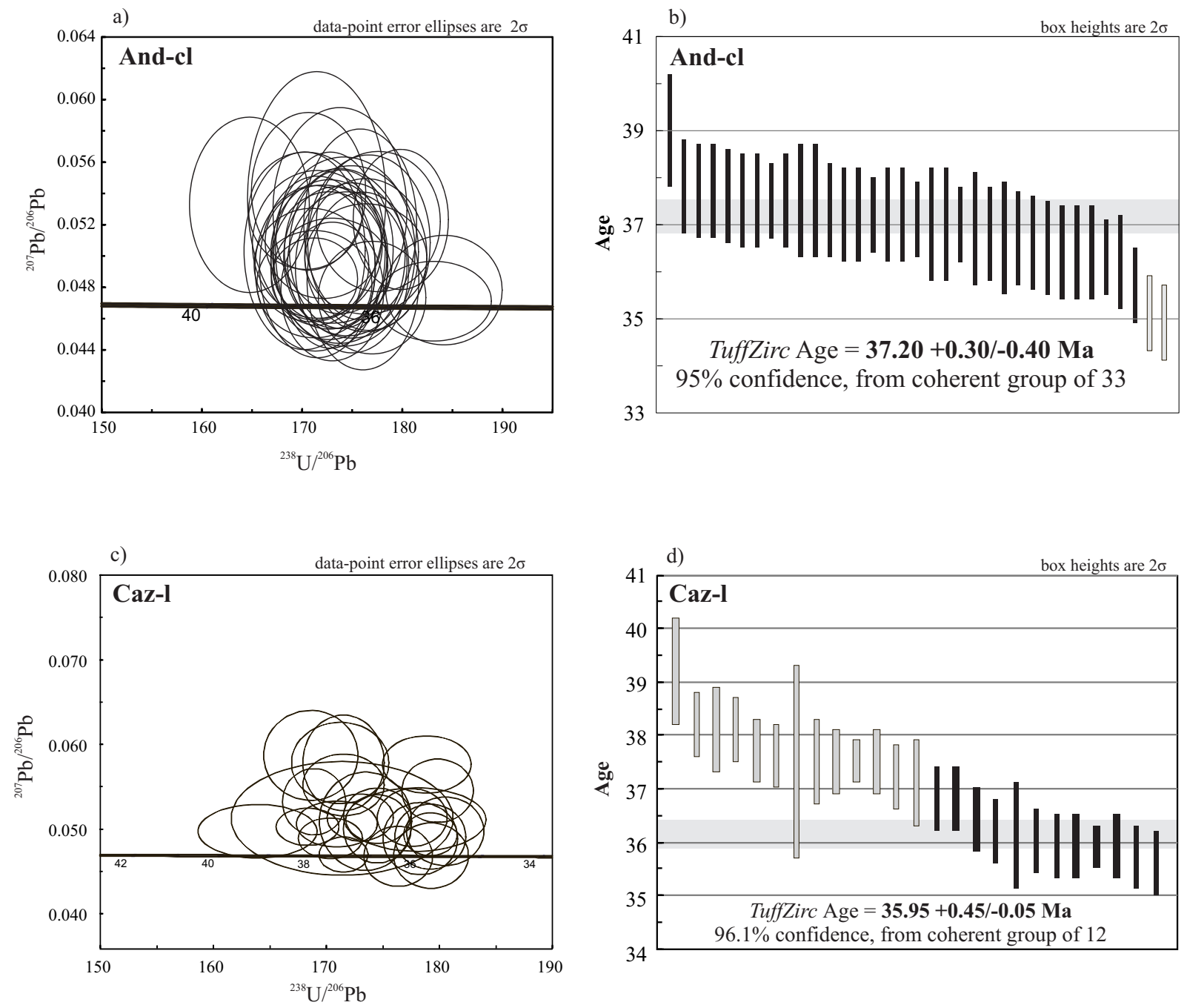

Figure 6. Zircon U-Pb data obtained by LA-ICP-MS for samples And-cl and Caz-l of El Cazadero andesite. a) Tera-Wasserburg diagram showing concordant data from sample $A$ nd-cl. b) Mean weight age diagram for this sample. c) Tera-Wasserburg diagram showing concordant data from sample Caz-l. d) Mean weight age diagram for this sample.

west of Durango City, around $130 \mathrm{~km}$ to the south-southeast of Santiago Papasquiaro. Equivalent basalts mapped in the study area consist of basaltic flows and dikes, which overlie and/or intrude the late Eocene-early Oligocene ignimbritic sequence. Small basalt flows crop out east of Santiago Papasquiaro (Figure 4). Also, some dikes and small flows crop out along the Santiago Papasquiaro-Nuevo Ideal highway and the Santiago Papasquiaro-Francisco Javier Leyva road. These lava flows usually present basal and upper breccias, and some glomerophenocrysts of $c a$. $15 \mathrm{~mm}$ (Tables 1 and 2). The basalts equivalent to the Metates Formation overlie unconformably the Santiago formation and are intercalated with Neogene-Quaternary unconsolidated deposits (Figure 4). Iriondo et al. (2004) obtained Ar-Ar isochron and plateau-like ages of $10.63 \pm 0.05$ $\mathrm{Ma}$ and $10.95 \pm 0.02 \mathrm{Ma}$ from one sample of these lavas, locating this unit at the base of the late Miocene.

\subsubsection{Neogene-Quaternary sediments}

The Santiago Papasquiaro half-graben topographic depression is filled by sand, conglomerate and lacustrine deposits (Figure 4). The lacustrine deposits are carbonate rich, light colored and composed mainly of fine material with isolated lithics, crystals and pumice, which are less than $5 \mathrm{~mm}$ size. They are intercalated with fine to coarse grain sand deposits that show cross bedding. Layering has variable thickness from 5 to $20 \mathrm{~cm}$. In the NeogeneQuaternary sediments there also are clast-supported conglomerates composed of subangular to subrounded volcanic and metamorphic rocks of $2 \mathrm{~mm}$ to $15 \mathrm{~cm}$ size. These conglomerates are intercalated with other deposits composed of isolated volcanic clasts of $\sim 20 \mathrm{~cm}$ and lacustrine fragments, all supported by a clayey matrix. Other deposits are composed of medium grain red sands with lacustrine deposit fragments. These sands show incipient stratification, in some places clay matrix is present. The 


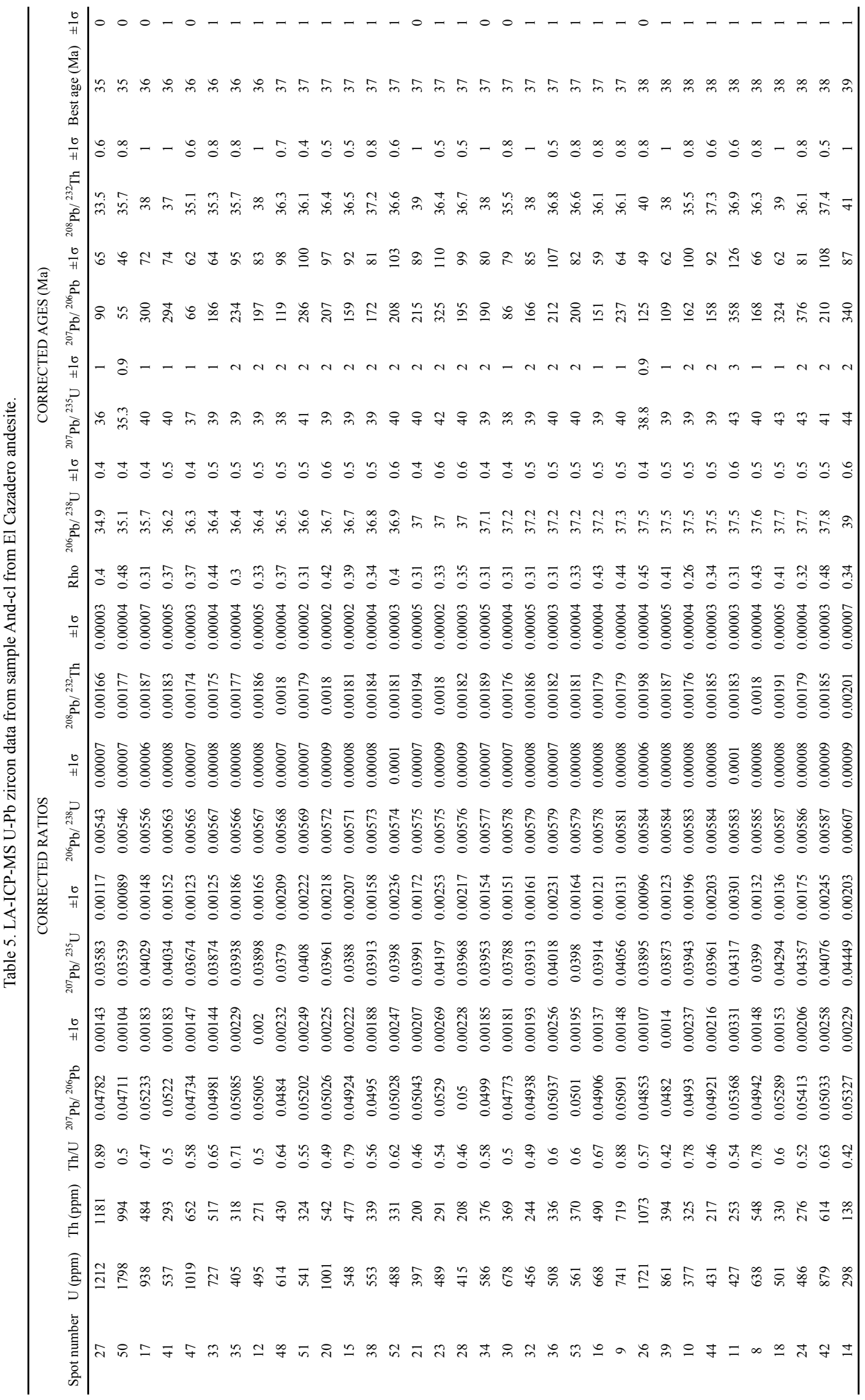




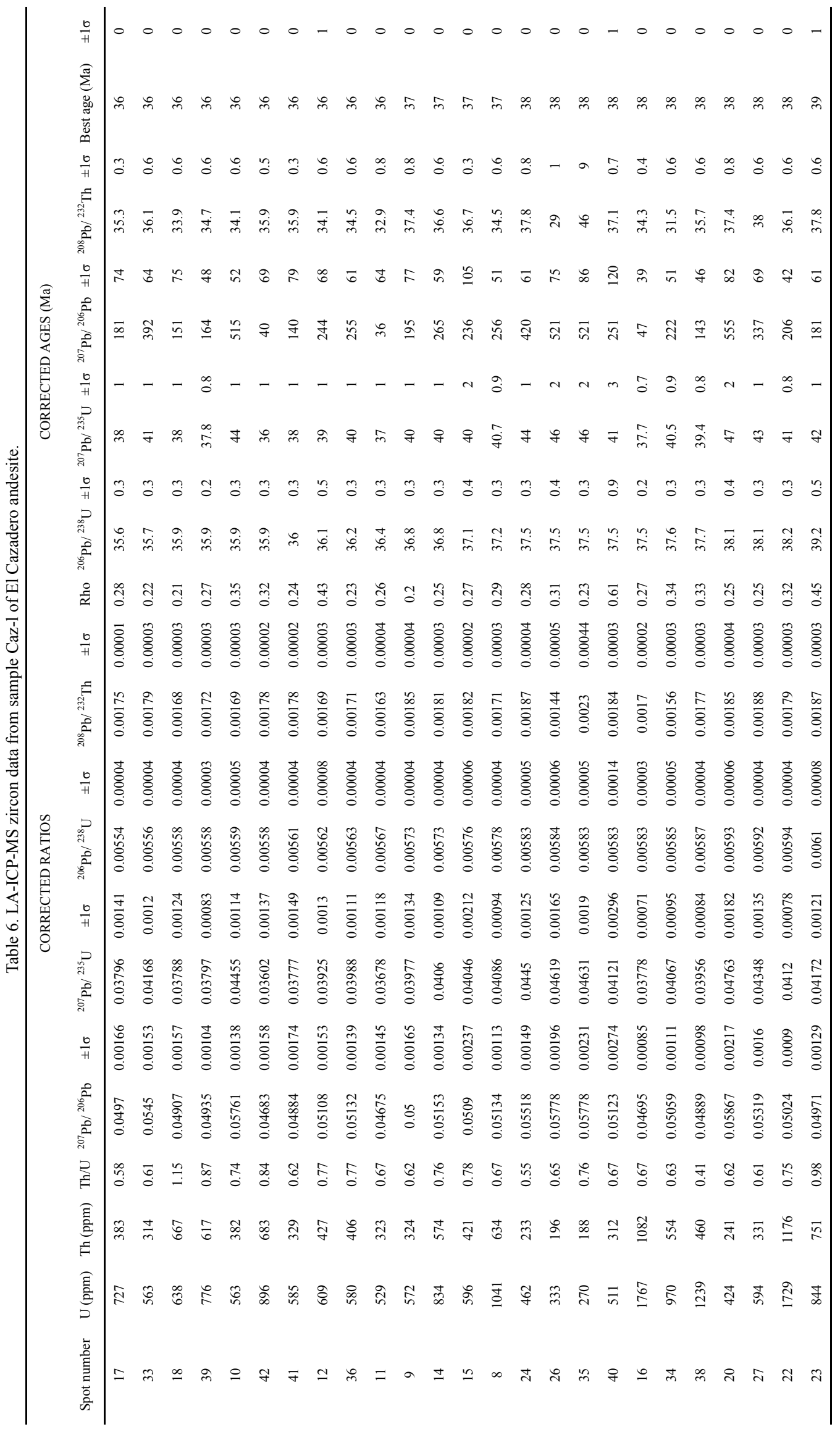



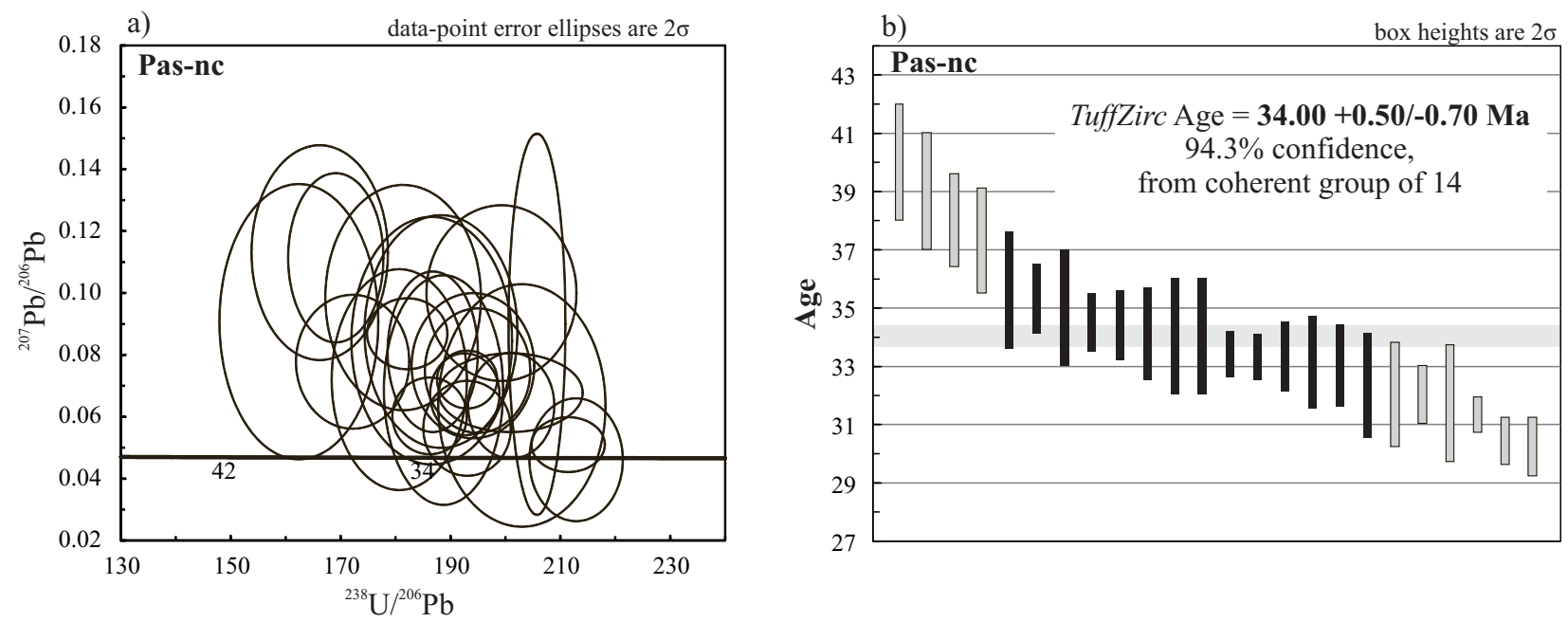

Figure 7. Zircon U-Pb data obtained by LA-ICP-MS for sample Pas- $n c$ of the Puente Negro ignimbrite. a) Tera-Wasserburg diagram showing concordant data from sample Pas-nc. b) Mean weight age diagram for this sample.

estimated thickness for the Neogene-Quaternary sediments is around $300 \mathrm{~m}$ (INEGI, 1990). These deposits contain intercalated basaltic lavas (equivalent to the Metates Formation) and overlie unconformably the Santiago formation and the Puente Negro ignimbrite, showing a stratigraphic range from Neogene to Quaternary (Figure 4).

\subsection{Dioritic intrusion}

A dioritic intrusive neck crops out west-southwest of Los Herrera (Figure 4, Tables 1 and 2). This intrusion was reported previously by Mungía-Rojas et al. (2000) and Luévano-Pinedo et al. (2003). This body intrudes rocks of the El Cazadero andesite of late Eocene age.

\section{Structure of the Santiago Papasquiaro valley}

The Santiago Papasquiaro valley is formed by NNW and NW striking blocks tilted to the southwest (Figures 3, 4 and 9). The tilted blocks of the Santiago Papasquiaro valley were formed in the intersection of two major fault systems: the San Luis-Tepehuanes NW-striking fault system (SLTFS) and the Río Chico-Otinapa NNW graben (RCOG) (Figures 1 and 3) (Nieto-Samaniego et al., 2005). The Tepehuanes and Santiaguillo grabens are part of the SLTFS (Figure 3) (Nieto-Samaniego et al., 2012). Between the Santiaguillo and Tepehuanes grabens there is a zone with NW faults that produce elongated blocks tilted to the southwest (Figures 3, 4 and 9). The second system is formed of several NNW grabens and half grabens that form a tectonic depression that is $\sim 150 \mathrm{~km}$ long and averages $10 \mathrm{~km}$ wide (Figure 3). The northernmost structure of the RCOG is the Santiago Papasquiaro half-graben, which is oriented $\mathrm{N} 15^{\circ} \mathrm{W}$ and is $\sim 40 \mathrm{~km}$ long and $\sim 10 \mathrm{~km}$ wide. Within the study area the master faults of both the SLTFS and RCOG are located in the western border of the Santiago Papasquiaro valley (Figures 3, 4 and 9). Those faults separate the Neogene-Quaternary sediments from the late Eocene-early Oligocene volcanic units. The estimated throw of the Santiago Papasquiaro halfgraben (RCOG) is around $200 \mathrm{~m}$, but considering throws of the adjacent major faults, the total throw is around 600 $\mathrm{m}$ (Figures 4 and 9). The throw of the SLTFS master fault is $500 \mathrm{~m}$, adding the throws of the adjacent major faults, the total estimated throw reaches $800 \mathrm{~m}$ (Figures 4 and 9).

The average strike of the measured planes is NNW, and there is no significant difference between northern and southern portions of the measured fault planes (Figure 10). As seen in Figure 3, the average strike of SLTFS and RCOG is very similar at Santiago Papasquiaro latitude. Although the slickenlines show large dispersion, the movement is mainly normal to left oblique (Figure 10). Calculated strain tensors, using the dynamic analysis of Spang (1972), show minimum principal stress oriented 230/01 for the northern part of the study area and 244/05 for the southern part (Figure 10). We can see that inversion results are similar for both analyses, considering separately northern and southern data; this means that very similar strain tensors were obtained for both SLTFS and the Santiago Papasquiaro half-graben (Figure 10).

\section{Geologic Evolution}

Most of the volcanic rocks in this portion of the Mesa Central were emplaced during the Eocene and Oligocene time. Two pulses can be identified: one occurred during the Paleocene-middle Eocene and the other during the late Eocene-early Oligocene (Figure 11). From the Miocene to Recent, volcanic activity was scattered and sporadic. 


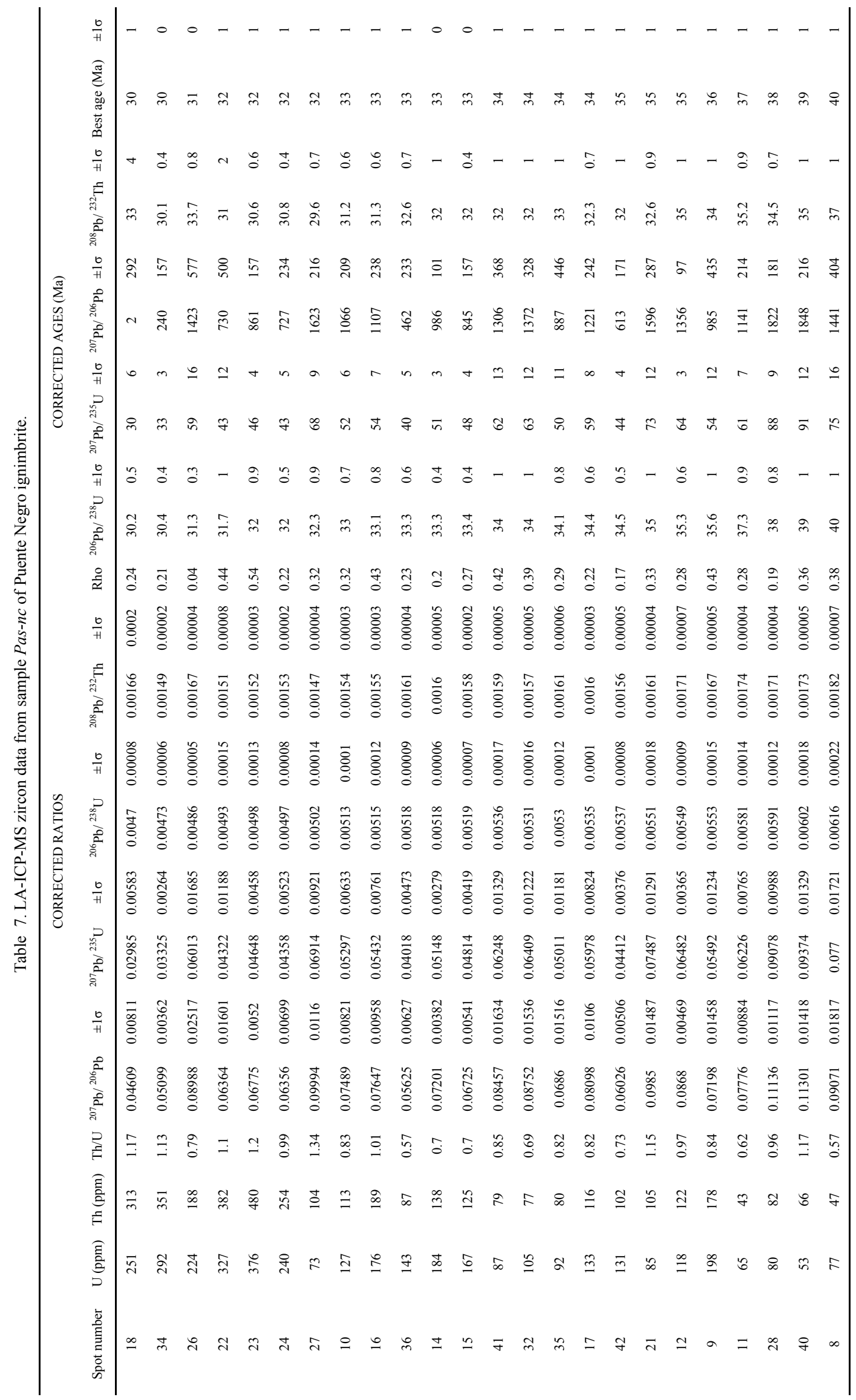



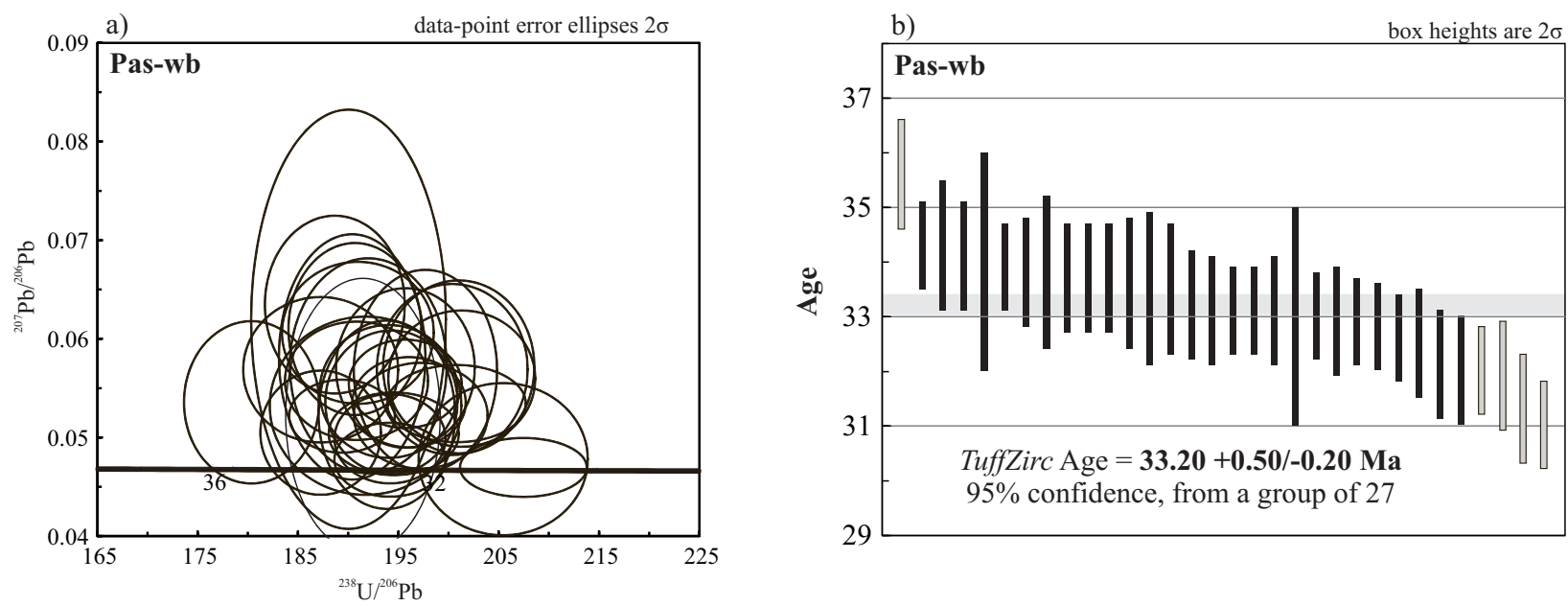

Figure 8. Zircon U-Pb data obtained by La-ICP-MS for sample Pas- $w b$ of the Balín ignimbrite. a) Tera-Wasserburg diagram showing concordant data from sample $P a s-w b$. b) Mean weight age diagram for this sample.

The Paleocene-middle Eocene event is characterized by volcanism that ranges in composition from rhyolite to andesite. Rocks of this volcanic pulse have been reported in Durango (McDowell and Keizer, 1977), Nazas (AguirreDíaz and McDowell, 1991), Santiago Papasquiaro and Nuevo Ideal (present work) with ages from 56 to $40 \mathrm{Ma}$ (Figure 11). The U-Pb age of 56.4 +0.50/-0.70 Ma (Figure 12 , Tables 3 and 9) was obtained from sample $G m-26$ from a rhyolite north of Nuevo Ideal (Table 3). The available data allows us to establish that this volcanic event has not been synchronic in the entire region, and that there was a hiatus in the volcanic activity after $56 \mathrm{Ma}$ in Nuevo Ideal, after 51 Ma in Santiago Papasquiaro and Durango, whereas in Nazas the hiatus began after $40 \mathrm{Ma}$ (Figure 11). It's important to notice the presence of a population of 90-80 Ma zircons in rhyolite sample $G m-26$ from the Nuevo Ideal region, $40 \mathrm{~km}$ southeast of Santiago Papasquiaro (Figure 12, Tables 3 and 9). Those zircons indicate that the rhyolite has incorporated zircons from Cretaceous granitic or volcanic rocks that must underlie the area. An example of this is an $87 \pm 1.8 \mathrm{Ma}(\mathrm{K}-$ Ar, hornblende) diorite pluton reported by Aguirre-Díaz and McDowell (1991) in the Nazas-Rodeo region, $\sim 90 \mathrm{~km}$ northeast of Nuevo Ideal.

The late Eocene-early Oligocene volcanic episode began $c a .38 \mathrm{Ma}$ and is composed of acid to intermediate rocks (Figure 11). In Santiago Papasquiaro the volcanism continued into the early Oligocene. In the Nuevo Ideal region the age of the Coneto Rhyolite, the youngest unit of this volcanic sequence, is unknown. Volcanic activity is reported from $31 \mathrm{Ma}$ to $c a .28 \mathrm{Ma}$ in Durango and from 34 to 29 Ma near Nazas (Figure 11).

Volcanic activity ceased in late Oligocene time, and continental epiclastics were deposited in topographic depressions. During Neogene and Quaternary time, nonconsolidated clay, sand and conglomerate were deposited. In the Miocene, basalt flows with ages $\sim 24$ Ma were emplaced in the Nazas region (Luhr et al., 2001), whereas in Santiago
Papasquiaro and Durango basalts are younger, with ages from 10 to $12 \mathrm{Ma}$ (Figure 11). The Durango Volcanic Field in Nuevo Ideal and Durango is composed of several volcanoes and basalt flows of Quaternary age (Albritton, 1958) (Figures 1, 2 and 11).

Extensional deformation (D1) initiated during the emplacement of the late Eocene-early Oligocene volcanic rocks. The coeval faulting and volcanism is inferred because the lower stratigraphic units show slightly greater tilts. D1 generated NW striking faults of the SLTFS in the north of the study area and NNW striking faults of the Santiago Papasquiaro half-graben in the south of the study area, creating an elongated depression where the Santiago formation was deposited. Some of the faults active during D1 were buried during deposition of the Santiago formation. We propose that RCOG began during D1 with the Santiago Papasquiaro half-graben and propagated southwards. This inference is based on the following observations: (a) vertical displacements of the RCOG diminish towards the south, from $\sim 600 \mathrm{~m}$ near Santiago Papasquiaro to $\sim 300 \mathrm{~m}$ near Otinapa, and the graben terminates $25 \mathrm{~km}$ south of Otinapa (Aranda-Gómez et al., 1997; Henry and Aranda-Gómez, 2000); (b) the basin fill erosion is more advanced in the Santiago Papasquiaro half-graben than in the southernmost regions, near Otinapa and Rio Chico, where the erosion is incipient; (c) sedimentary deposits that fill the northern depressions are more than $300 \mathrm{~m}$ thick and thin southward to tens of meters (Aranda-Gómez et al., 1997; Henry and Aranda-Gómez, 2000); (d) the basin system slopes northward, going gradually from average heights of 2100 masl in the south to 1700 masl in the north. We interpret that D1 initiated synchronously with the final stage of late Eocene-early Oligocene volcanism because, even though the collected data are scarce, the average tilting of El Cazadero andesite and Puente Negro ignimbrite is $\sim 17^{\circ} \mathrm{SW}$, whereas the Balín ignimbrite average tilting is $\sim 12^{\circ} \mathrm{SW}$, forming a slight angular unconformity that could be observed in the 


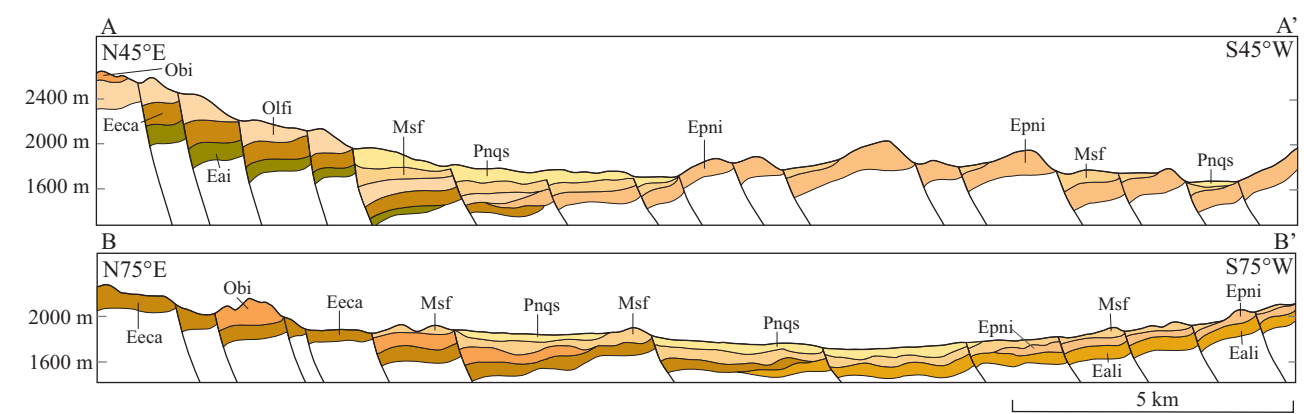

Figure 9. Cross sections of Santiago Papasquiaro valley in which the tilted block structure is observed. A-A' is a cross section of the SLTFS influence area, and B-B' is of the ORCG influence area. Unit names and color patterns as in Figure. 4.
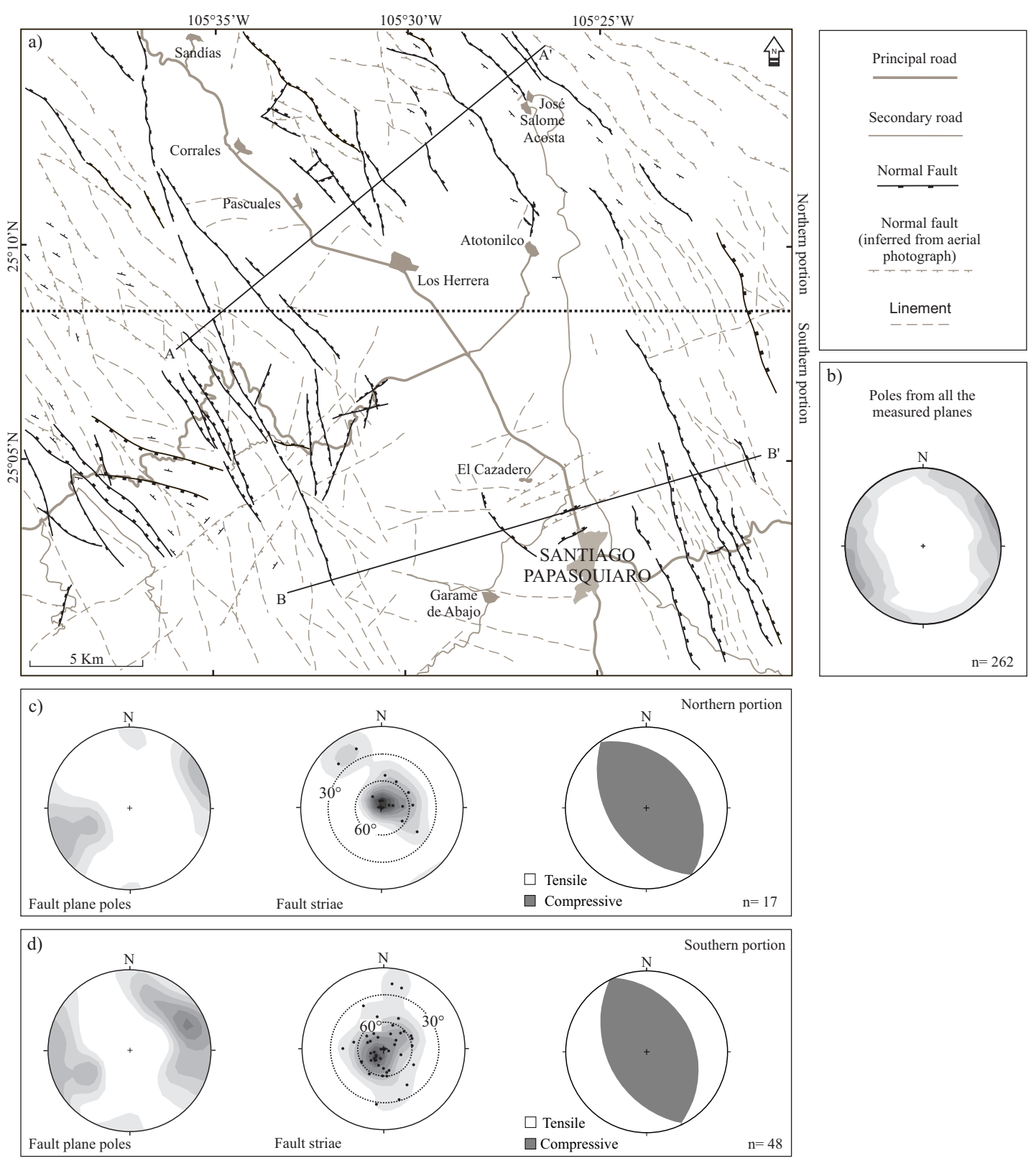

Figure 10. a: Map showing the principal structures in the studied area. b: Contour diagram that show poles of planes measured in all the study area. c: Contour diagrams of poles of fault planes, fault striae and deformation tensors presented as "beach ball" Diagrams, measured in the northern portion of the study area. d: Contour diagrams of poles of fault planes, fault striae and deformation tensors presented as "beach ball" Diagrams, measured in the southern portion of the study area. n: Data plotted in each diagram. 


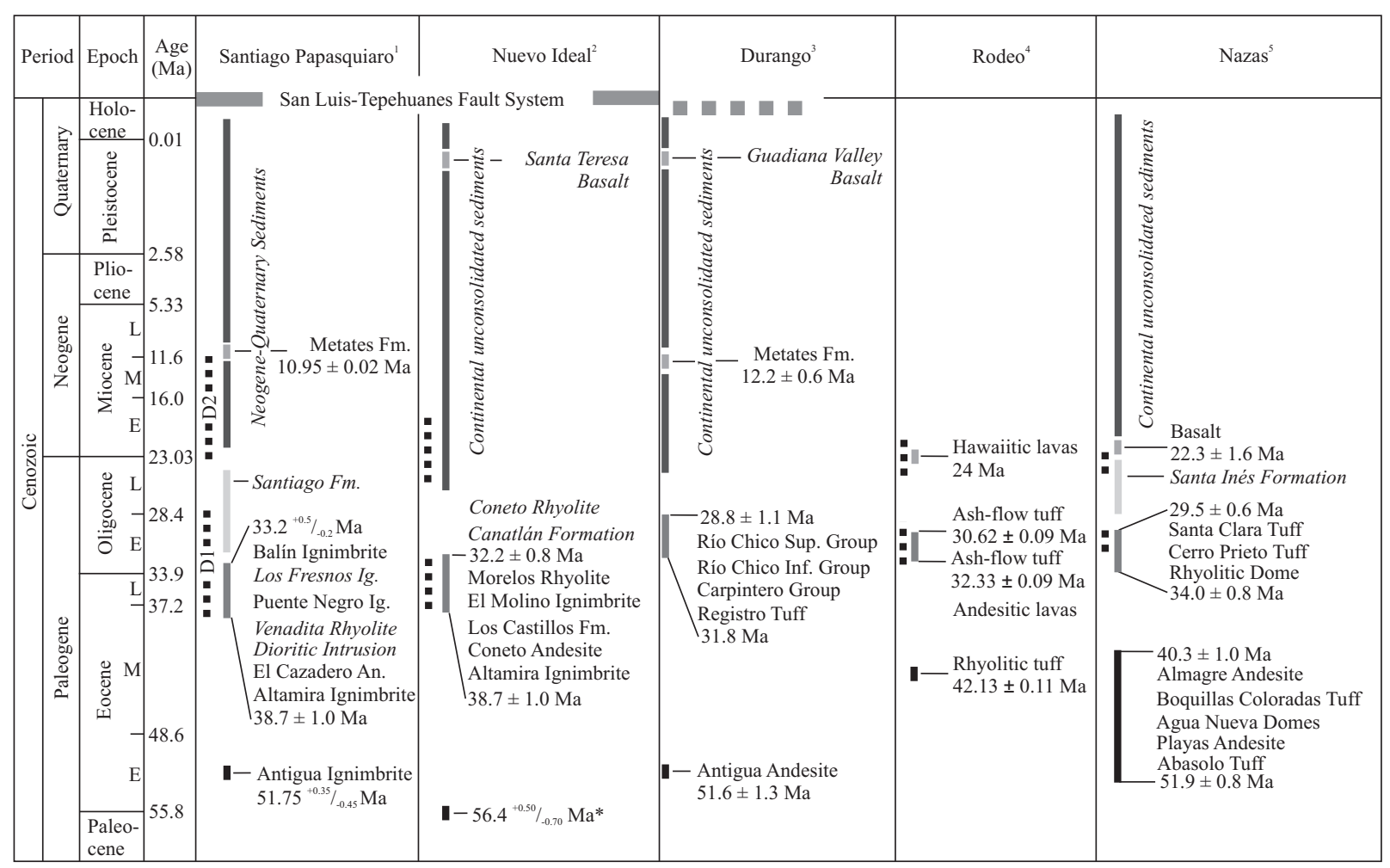

Figure 11. Regional lithostratigraphic correlation. ${ }^{1}$ Lithostratigraphic column from this work. ${ }^{2}$ Nieto-Samaniego et al. (2012). ${ }^{3}$ McDowell and Keizer (1977). ${ }^{4}$ Lhur et al. (2001). ${ }^{5}$ Aguirre-Díaz and McDowell (1991). Dotted lines represent the main phases of extensional deformation. Two extensional deformation phases were recognized in Santiago Papasquiaro region (D1 and D2). "U-Pb age from rhyolite sample Gm-26.
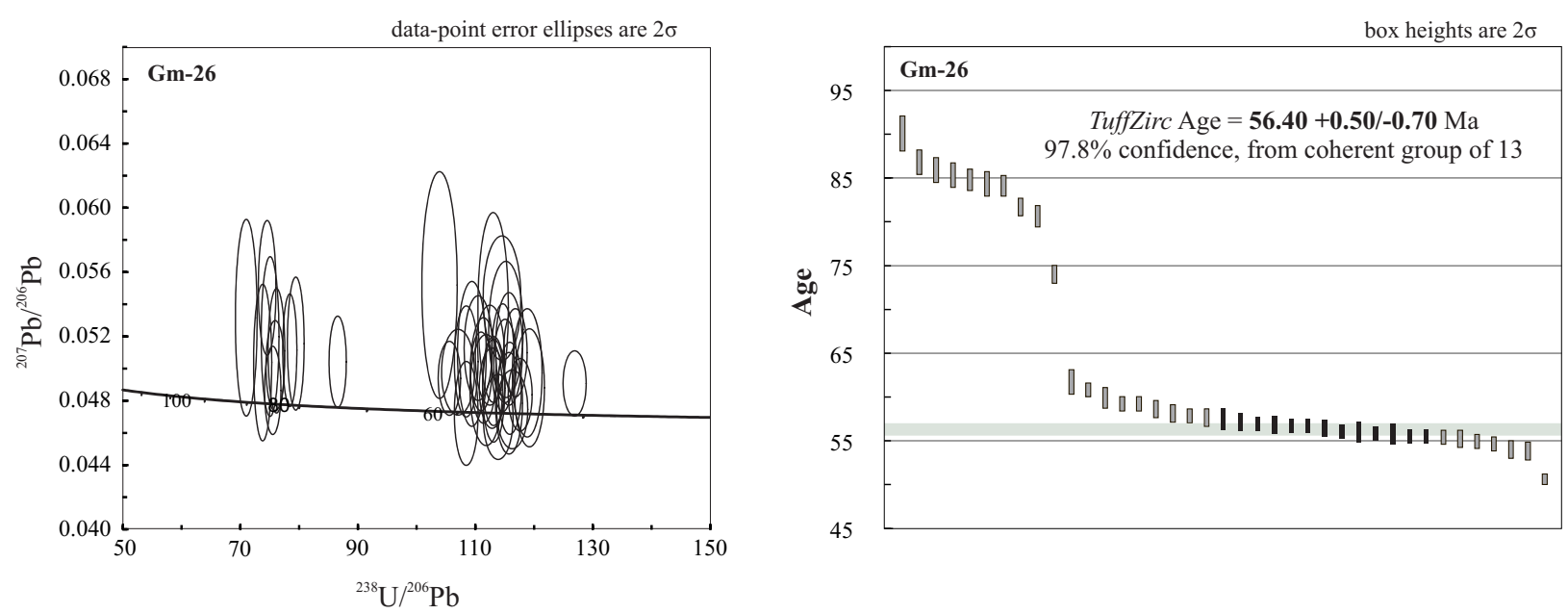

Figure 12. Zircon U-Pb data obtained by La-ICP-MS of sample $\mathrm{Gm}-26$ of the Nuevo Ideal region. a) Tera-Wasserburg diagram showing concordant data from rhyolite sample $G m-26$. b) Mean weight age diagram for this sample.

transect across Santiago Papasquiaro-Los Altares highway.

In the early-middle Miocene time, after the deposition of Santiago formation, a second extensional deformation phase (D2) took place that reactivated NNW striking faults of the Santiago Papasquiaro half-graben. D2 was inferred from faults that cut and tilt the Santiago formation. Some of these faults can be observed on the Santiago Papasquiaro-
Garame de Abajo road and Santiago Papasquiaro-Nuevo Ideal highway. Some D2 faults were used later by feeder dikes of the equivalent Metates Formation; these dikes can be observed along the Santiago Papasquiaro-Nuevo Ideal highway and Santiago Papasquiaro-Francisco Javier Leyva road. Observed displacements on D2 NW faults of San Luis-Tepehuanes are less than $10 \mathrm{~m}$; displacement in 


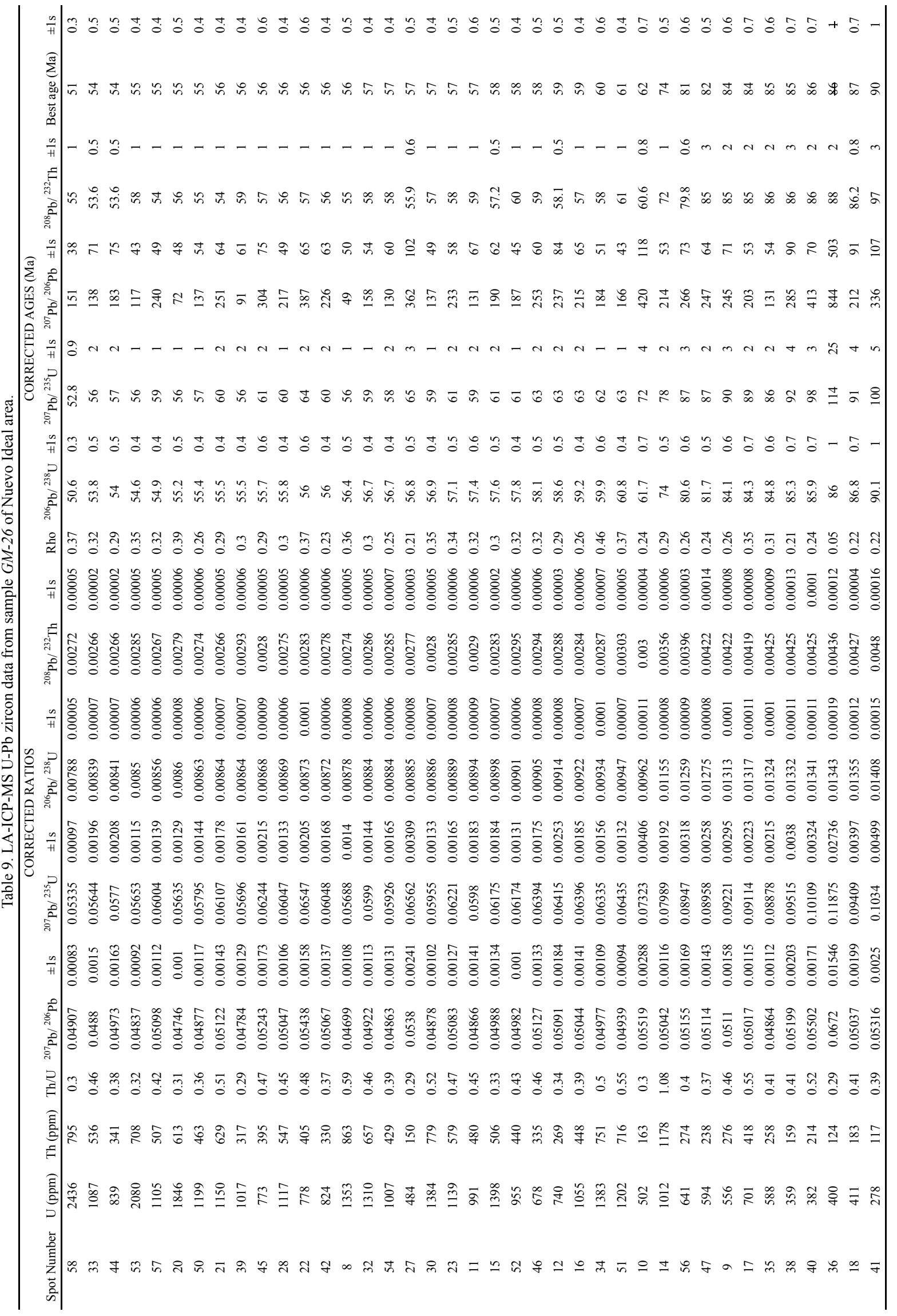


this system might have migrated to the east-southeast to the Santiaguillo graben where the peak of deformation ended in early Miocene (Nieto-Samaniego et al., 2012).

Minor extensional deformation (D3) in the PlioceneQuaternary is evidenced from NE faults that affected the Neogene-Quaternary non-consolidated sediments. North of Santiago Papasquiaro two faults were measured in the recent basin fill deposits, with displacements of $\sim 2$ meters (Figure 13). Nieto-Samaniego et al. (2012) documented seismic activity in the Santiaguillo graben region. The reported seismicity supports that there is active deformation in the region, which could be responsible for the younger faults mapped in the study area.

\section{Conclusions}

The main conclusions from this study as well as the improvements in the knowledge of Cenozoic evolution of the northwestern Mesa Central of Mexico are:

- Six new U-Pb isotopic dates contribute to constraining the time of two volcanic pulses during the Cenozoic and the hiatus between them: The first volcanic pulse, referred to in the text as the Paleocene-middle Eocene volcanic pulse, is represented in the study area by $51.7 \mathrm{Ma}$ rocks. The second volcanic pulse occurred in the late Eoceneearly Oligocene and spanned from: 38.7 to $33.2 \mathrm{Ma}$.

- Three units with late Oligocene to Quaternary ages were distinguished in the study area: Santiago formation, basalts equivalent to the Metates Formation and non-consolidated sediments of the Neogene-Quaternary.

- $\quad$ Reported 56.4 and 51.7 Ma volcanic rocks confirm the existence of a pre-Oligocene volcanism pulse in the northwestern portion of the Mesa Central.

- Oligocene volcanism has been reported extensively

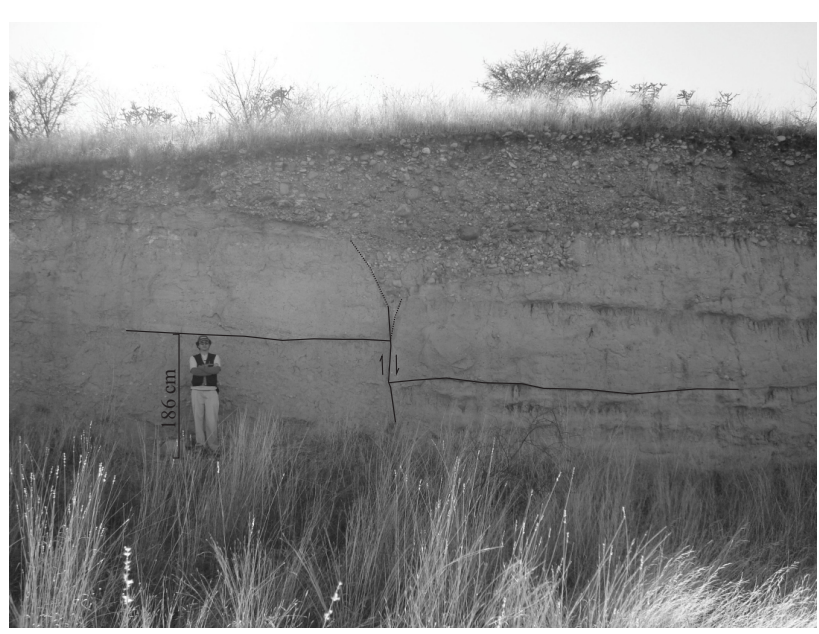

Figure 13. Photograph of NE striking faults that affect some of the NeogeneQuaternary unconsolidated deposits north of Santiago Papasquiaro. in the Mesa Central. In the study area this volcanic pulse initiated at $c a$. 37-38 Ma, shortly earlier than in other areas, and lasted $c a .5 \mathrm{Ma}$. There is a hiatus between those two volcanic pulses, as has been previously reported in other areas of the Mesa Central (Nieto-Samaniego et al., 2005; Loza-Aguirre et al., 2008). The data presented here allows arguing that this hiatus lasted $c a .10 \mathrm{Ma}$ in Santiago Papasquiaro.

- Three deformational phases where identified in the study area: D1 during the late Eocene-early Oligocene formed NW striking faults of the San Luis-Tepehuanes fault system and NNW striking faults of the Santiago Papasquiaro half-graben. The deformation migrated southward from Santiago Papasquiaro to the Rio Chico-Otinapa region. D2 during the early-middle Miocene reactivated NNW and faults NW. D3 during Pliocene-Quaternary formed minor displacement NE striking faults that cut unconsolidated deposits.

- Late Oligocene to Quaternary units record a new stage in the tectono-magmatic evolution of this region of the MC: the end of explosive acid volcanism of the SMOc, changing to an erosional phase with deposition of continental sediments in graben structures with small amounts of basaltic magmatism.

In the study area, crustal extension and volcanism occurred synchronously from late Eocene to present. The peak of extension and volcanism extended from late Eocene to early Oligocene.

\section{Acknowledgements}

The present work was financed by CONACYT projects 80142 and 049049 . All the lab work was done at the Centro de Geociencias, Universidad Nacional Autónoma de México. We thank Juan Tomas Vázquez Ramírez for thin section preparation. Reviews by Fred McDowell and Christopher Henry substantially improved this manuscript.

\section{References}

Aguirre-Díaz, G.J., McDowell, F.W., 1991, The volcanic section at Nazas, Durango, Mexico, and the possibility of widespread Eocene volcanism within the Sierra Madre Occidental: Journal of Geophysical Research, 96, 13373-13388.

Aguirre-Díaz, G.J., McDowell, F.W., 1993, Nature and timing of faulting and synextensional magmatism in the southern Basin and Range, central-eastern Durango, Mexico: Geological Society of America Bulletin, 105, 1435-1444.

Albritton, Jr., C.C., 1958, Quaternary Stratigraphy of the Guadiana Valley, Durango, Mexico: Bulletin of the Geological Society of America, 69, 1197-1216.

Andersen T., 2002, Correction of common lead in U-Pb analysis that do not report ${ }^{204} \mathrm{~Pb}$ : Chemical Geology, 192, 59-79. 
Aranda-García, M., Gómez-Luna, M.A., Contreras y Montero, B., 1987, El Jurásico Superior (Kimmeridgiano-Tithoniano) en el área de Santa María del Oro, Durango, México: Revista de la Sociedad Mexicana de Paleontología, 1, 75-87.

Aranda-Gómez, J.J., Henry, C.D., Luhr, J.F. and McDowell, F.W., 1997, Cenozoic volcanism and tectonics in NW Mexico a transect across the Sierra Madre Occidental volcanic field and observations on extension related magmatism in the southern Basin and Range and Gulf of California tectonic provinces, in Aguirre-Díaz, G.J., ArandaGómez, J.J., Carrasco-Nuñez, G. and Ferrari, L. (eds.), Magmatism and tectonics in the central and northwestern Mexico a selection of the 1997 IAVCEI general Assembly excursions: México D.F., México, Universidad Nacional Autónoma de México, Instituto de Geología, 41-84.

Araujo-Mendieta, J., Arenas-Partida, R., 1986, Estudio TectónicoSedimentario en el Mar Mexicano, Estados de Chihuahua y Durango: Boletín Sociedad Geológica Mexicana, 47, 43-71.

Contreras-Montero, B., Martínez-Cortes, A., Gómez-Luna, M.E., 1988, Bioestratigrafía y Sedimentología del Jurásico Superior en San Pedro del Gallo, Durango, México: Revista del Instituto Mexicano del Petróleo, 20, 5-49.

Córdoba, D.A., 1963, Geología de la región entre Río Chico y Llano Grande, Municipio de Durango, Estado de Durango, in Cserna, Z. (ed.), Estudios geológicos en los Estados de Durango y San Luis Potosí: México, D.F., Méxicoo, Universidad Nacional Autónoma de México, Instituto de Geología, 71, 1-21.

Córdoba, D.A., 1988, Estratigrafía de las rocas volcánicas de la región entre Sierra de Gamón y Laguna de Santiaguillo, Estado de Durango: Revista del Instituto de Geología, Universidad Nacional Autónoma de México, 7, 136-147.

Ferrari, L., Valencia-Moreno, M., Bryan, S., 2005, Magmatismo y tectónica en la Sierra Madre Occidental y su relación con la evolución de la margen occidental de Norteamérica: Boletín de la Sociedad Geológica Mexicana, 57, 343-378.

Henry, C.D., Aranda-Gómez, J.J., 2000, Plate interactions control middlelate Miocene, proto-Gulf and Basin and Range extension in the southern Basin and Range: Tectonophysics, 318, 1-26.

Instituto Nacional de Estadística Geografía e Informática (INEGI), 1990, Carta Hidrológica de Aguas Subterráneas, Santiago Papasquiaro, G13-8, Esc. 1:250000: México, D.F., México, Secretaría de Programación y Presupuesto, Instituto Nacional de Estadística, Geografía e Informática, 1 mapa.

Instituto Nacional de Estadística Geografía e Informática (INEGI), 2000, Carta Topográfica, Santiago Papasquiaro, G13C48, Esc. 1:50000: México, D.F., México, Secretaría de Programación y Presupuesto, Instituto Nacional de Estadística, Geografía e Informática, 1 mapa.

Iriondo, A., Kunk, M.J., Winick, J.A., CRM, 2003, ${ }^{40} \mathrm{Ar} /{ }^{39} \mathrm{Ar}$ Dating Studies of Minerals and Rocks in various areas in Mexico: USGS/ CRM Scientific Collaboration (Part I): Denver, Colorado, USGS 2004, disponible en http://pubs.usgs.gov/of/2003/ofr-03-020/OFR03-020-508eng.pdf

Iriondo, A., Kunk, M.J., Winick, J.A., CRM, 2004, ${ }^{40} \mathrm{Ar} /{ }^{39} \mathrm{Ar}$ Dating Studies of Minerals and Rocks in various areas in Mexico: USGS/ CRM Scientific Collaboration (Part II): Denver, Colorado, USGS 2004, http://pubs.usgs.gov/of/2004/1444/OF2004 1444 508.pdf

Loza-Aguirre, I., Nieto-Samaniego, A.F., Alaniz-Álvarez, S.A., Iriondo, A., 2008, Relaciones estratigráfico-estructurales en la intersección del sistema de fallas San Luis-Tepehuanes y el graben de Aguascalientes, México central, Revista Mexicana de Ciencias Geológicas, 25(3), 533-548.

Ludwig K.R., 2008, Isoplot 3.7. A geochronological toolkit for Microsoft Excel: Berkeley, California, USA, Berkeley Geochronology Center Special Publication, No. 4, 77pp, disponible en http://www.bgc.org/ isoplot_etc/isoplot/
Luévano-Pinedo, J.A., Millán-Quezada, L., Guereca-Meza, R., 2003, Carta Geológico-Minera Santiago Papasquiaro G13-C48, escala 1:50000: Pachuca, Hidalgo, Consejo de Recursos Minerales, 1 hoja con texto explicativo.

Luhr, J.F., Henry, C.D., Housh, T.B., Aranda-Gómez, J.J., McIntosh, W.C., 2001, Early extension and associated mafic alkalic volcanism from the southern Basin and Range Province: Geology and petrology of the Rodeo and Nazas volcanic fields, Durango, México: Geological Society of America Bulletin, 113, 760-773.

McDowell, F.W., Keizer, R.P., 1977, Timing of mid-Tertiary volcanism in the Sierra Madre Occidental between Durango City and Mazatlan, Mexico: Geological Society of America Bulletin, 88, 1479-1487.

McDowell, F.W., Clabaugh, S.E., 1981, The igneous history of the Sierra Madre Occidental and its relation to the tectonic evolution of western Mexico: Revista Instituto de Geología, Universidad Nacional Autónoma de México, 5, 195-205.

Mungía-Rojas, P., García-Padilla, J.L., Armenta-Román, R., CruzPérez, R., Camacho, J.M., De Santiago-Céspedes, J., 1998, Carta Geológico-Minera, Durango G13-11, escala 1:250000, Pachuca, Hidalgo, Consejo de Recursos Minerales, 1 hoja con texto explicativo.

Mungía-Rojas, P., García-Padilla, J.L., Armenta-Román, R., Camacho, J.M., 2000, Carta Geológico-Minera, Santiago Papasquiaro G13-8, escala 1:250000: Pachuca, Hidalgo, Consejo de Recursos Minerales, 1 hoja con texto explicativo.

Nieto-Samaniego, A.F., Alaniz Alvarez, S.A., Camprubí, A., 2005, La Mesa Central de México: estratigrafía, estructura y evolución tectónica cenozoica: Boletín de la Sociedad Geológica Mexicana, 57, 285-317.

Nieto-Samaniego, A. F., Barajas-Gea, C. I., Gómez-González, J. M.; Rojas, A., Alaniz-Alvarez, S. A., Xu, S.-S., 2012, Geología, evolución estructural (Eoceno al actual) y eventos sísmicos del Graben de Santiaguillo, Durango, México: Revista Mexicana de Ciencias Geológicas, 29, 115-130.

Servicio Geológico Mexicano (SGM), 2007, Carta Geológica de la República Mexicana, escala 1:2000000, Pachuca, Hidalgo, Servicio Geológico Mexicano, 1 mapa.

Solari, L.A., Gómez-Tuena, A., Bernal, J.P., Pérez-Arvizu, O., Tanner, M., 2010, U-Pb zircon geochronology by an integrated LA-ICPMS microanalytical workstation: achievements in precision and accuracy: Geostandards and Geoanalytical Research, 34, 5-18.

Solari, L. A., and Tanner M., 2011, UPb.age, a fast reduction script for LA-ICP-MS U-Pb geochronology: Revista Mexicana de Ciencias Geológicas, 28, 83-91.

Solé, J., Salinas, J.C., González-Torres, E., Cendejas Cruz, J.E., 2007, Edades $\mathrm{K} / \mathrm{Ar}$ de 54 rocas ígneas y metamórficas del occidente, centro y sur de México: Revista Mexicana de Ciencias Geológicas, 24, 104-119.

Swanson, E.R., Keizer, R.P., Lyons, J.I., Clabaugh, S.E., 1978, Tertiary volcanism and caldera development near Durango City, Sierra Madre Occidental, Mexico: Geological Society of America Bulletin, 89, 1000-1012.

Zaldívar, R. J., Garduño, M. V. H., 1984, Estudio estratigráfico y estructural de las rocas del Paleozoico Superior de Santa María del Oro, Durango y sus implicaciones tectónicas: Sociedad Geológica Mexicana, Memorias $7^{\text {a }}$ Convención Nacional, 28-39.

Manuscript received: April 4, 2012.

Corrected manuscript received: June 7, 2012.

Manuscript accepted: June 6, 2012. 